\title{
The Betic Ophiolites and the Mesozoic Evolution of the Western Tethys
}

\author{
Encarnación Puga ${ }^{1, *}$, Antonio Díaz de Federico ${ }^{1}$, Mark Fanning ${ }^{2}$, José Miguel Nieto ${ }^{3}$, \\ José Ángel Rodríguez Martínez-Conde ${ }^{4}$, Miguel Ángel Díaz Puga ${ }^{5}$, José Antonio Lozano ${ }^{1}$, \\ Gianluca Bianchini ${ }^{6}$, Claudio Natali ${ }^{6}$ and Luigi Beccaluva ${ }^{6}$ \\ 1 Instituto Andaluz de Ciencias de la Tierra (CSIC-UGR), Avda. de las Palmeras 4, 18100 Armilla, Granada, \\ Spain; adiazdef@msn.com (A.D.d.F.); jalozano@ugr.es (J.A.L.) \\ 2 Research School of Earth Sciences, The Australian National University, Mills Road, ACT 0200 Canberra, \\ Australia; Mark.Fanning@anu.edu.au \\ 3 Departamento de Ciencias de la Tierra, Universidad de Huelva, 21071 Huelva, Spain; jmnieto@uhu.es \\ 4 Departamento de Ingeniería Minera, Geológica y Cartográfica, Universidad Politécnica de Cartagena, \\ 30203 Cartagena, Spain; josea.rmconde@upct.es \\ 5 Parque Natural y Nacional de Sierra Nevada, Consejería de Medio Ambiente y Ordenación del Territorio, \\ 18191 Pinos Genil, Spain; miguel.diaz.puga@juntadeandalucia.es \\ 6 Dipartimento di Scienze della Terra, Università di Ferrara, Via Saragat 1, 44100 Ferrara, Italy; \\ gianluca.bianchini@unife.it (G.B.); claudio.natali@unife.it (C.N.); luigi.beccaluva@unife.it (L.B.) \\ * Correspondence: epuga@ugr.es; Tel.: +34 678277242
}

Academic Editors: Antonio Acosta-Vigil, Basilios Tsikouras and Jesús Martínez Frías Received: 17 January 2017; Accepted: 6 April 2017; Published: 20 April 2017

\begin{abstract}
The Betic Ophiolites consist of numerous tectonic slices, metric to kilometric in size, of eclogitized mafic and ultramafic rocks associated to oceanic metasediments, deriving from the Betic oceanic domain. The outcrop of these ophiolites is aligned along $250 \mathrm{~km}$ in the Mulhacén Complex of the Nevado-Filábride Domain, located at the center-eastern zone of the Betic Cordillera (SE Spain). According to petrological/geochemical inferences and SHRIMP (Sensitive High Resolution Ion Micro-Probe) dating of igneous zircons, the Betic oceanic lithosphere originated along an ultra-slow mid-ocean ridge, after rifting, thinning and breakup of the preexisting continental crust. The Betic oceanic sector, located at the westernmost end of the Tethys Ocean, developed from the Lower to Middle Jurassic (185-170 Ma), just at the beginning of the Pangaea break-up between the Iberia-European and the Africa-Adrian plates. Subsequently, the oceanic spreading migrated northeastward to form the Ligurian and Alpine Tethys oceans, from 165 to $140 \mathrm{Ma}$. Breakup and oceanization isolated continental remnants, known as the Mesomediterranean Terrane, which were deformed and affected by the Upper Cretaceous-Paleocene Eo-Alpine high-pressure metamorphic event, due to the intra-oceanic subduction of the Jurassic oceanic lithosphere and the related continental margins. This process was followed by the partial exhumation of the subducted oceanic rocks onto their continental margins, forming the Betic and Alpine Ophiolites. Subsequently, along the Upper Oligocene and Miocene, the deformed and metamorphosed Mesomediterranean Terrane was dismembered into different continental blocks collectively known as AlKaPeCa microplate (Alboran, Kabylian, Peloritan and Calabrian). In particular, the Alboran block was displaced toward the SW to occupy its current setting between the Iberian and African plates, due to the Neogene opening of the Algero-Provençal Basin. During this translation, the different domains of the Alboran microplate, forming the Internal Zones of the Betic and Rifean Cordilleras, collided with the External Zones representing the Iberian and African margins and, together with them, underwent the later alpine deformation and metamorphism, characterized by local differences of P-T (Pressure-Temperature) conditions. These Neogene metamorphic processes, known as Meso-Alpine and Neo-Alpine events, developed in the Nevado-Filábride Domain under Ab-Ep amphibolite and greenschists facies conditions, respectively, causing retrogradation and intensive deformation of the Eo-Alpine eclogites.
\end{abstract}


Keywords: zircon U-Pb SHRIMP dating; eclogitized ophiolites; Pangaea break-up; Western Tethys; Betic Cordillera

\section{Introduction}

The ultramafic and mafic rocks included in the Mulhacén Complex of the Betic Cordillera (SE Spain; Figure 1) have been interpreted as an eclogitized ophiolite association, i.e., metamorphosed remnants of a Mesozoic oceanic lithosphere since the 1970s (Puga [1], Puga and Díaz de Federico [2]). This hypothesis relating the Betic Ophiolite Association (hereafter named as BOA following Puga [3]) to a Mesozoic oceanic basin was criticized at the beginning, due to the paucity of outcrops conforming to the three layers model defined for Ophiolites in the Penrose Conference (1972), i.e., sections including peridotites/serpentinites, gabbros/basalts and deep sea sediments, such cherts, hypothetically corresponding to the stratigraphy of the oceanic lithosphere. In spite of the criticism, the Betic Ophiolites were identified as Mid-Oceanic-Ridge MOR-type by Puga [1,3], Bodinier et al. [4], Morten et al. [5], Puga et al. [6,7], who investigating BOA basic and ultramafic lithologies emphasized geochemical analogies with the rocks formed along the Atlantic Ridge and those included within the Jurassic Alpine-Apenninic Ophiolites. Moreover, later palaeogeographic, petrologic and geochemical studies [8-11] corroborated the ophiolitic origin of the BOA rocks. Nevertheless, Gómez-Pugnaire et al. [12] highlighted apparent petrological incongruence, emphasizing that the geochemical composition of Betic basalts/gabbros do not conform to Normal Mid Oceanic Ridge Basalt (N-MORB) features, i.e., tholeiitic character and extreme depletion in incompatible trace elements, and/or that the Betic ultramafic rocks tend to be less residual (i.e., lherzolite, scarcely depleted by partial melting) with respect to the abyssal peridotites having prevalent harzburgite composition.

This criticism on the oceanic nature of the BOA has been largely bypassed by recent papers which coupled radiometric dating to new petrological and geochemical studies (such as those in [13-23], among others), certainly ascribing the provenance of some BOA outcrops to a MORB-type tectonic setting, or to an Ocean-Continent-Setting (OCT). This hypothesis conforms to the interpretations proposed for ophiolite sequences of the Alps and Apennines as shown in [24-31]. Worth of note, recent oceanographic studies emphasize that the petrological characteristics of the current day oceanic rocks are more heterogeneous to that assumed in the past [32-36] and, hence, the "ophiolite concept" interpreted as "fossil oceanic lithosphere with a unique and complete lithologic sequence" has also to be revisited and updated [33].

Therefore, the aim of this contribution is to summarize the current understanding of BOA sequences, emphasizing analogies and differences with the adjoining rock associations and synthetizing possible geodynamic relationships. In this view, the BOA represents a key jigsaw of the Mesozoic Tethys puzzle and the definition of its paleogeographic and geodynamic evolution contributes to the understanding of the current geological configuration of the Central-Western Mediterranean area.

\section{Geographical and Geological Setting of the Betic Ophiolites}

The Betic Ophiolites (BOA), crop out discontinuously along some $250 \mathrm{~km}$ in the central and eastern sectors of the Betic Cordillera (SE Spain) (Figure 1). These ophiolites are represented by tectonic slabs ranging in size from metres to kilometres and made up of metamorphosed ultramafic and mafic lithologies sometimes associated to sedimentary rocks. Figure 1 shows the location of the most significant betic ophiolitic outcrops from which most of the petrological, geochemical and geochronological data mentioned in this study have been obtained. These ophiolites are exclusively located in the Mulhacén Complex (MC), in the central and eastern area of the Betic Cordillera, and are never found in the underlying Veleta Complex (VC) $[13,16,23,37,38]$. This suggests that these two complexes pertained to different palaeogeographic domains before and during the Jurassic-Cretaceous period, when the ophiolites originated from exhumation of an oceanic floor $[8,10,15,17-19,39,40]$. 
At present the rocks of the VC crop out forming several tectonic windows below the (MC), and both metamorphic complexes, forming the Nevado-Filábride Domain, are the deepest in the current tectonic pile forming the Betic Cordilleras (Figure 1).

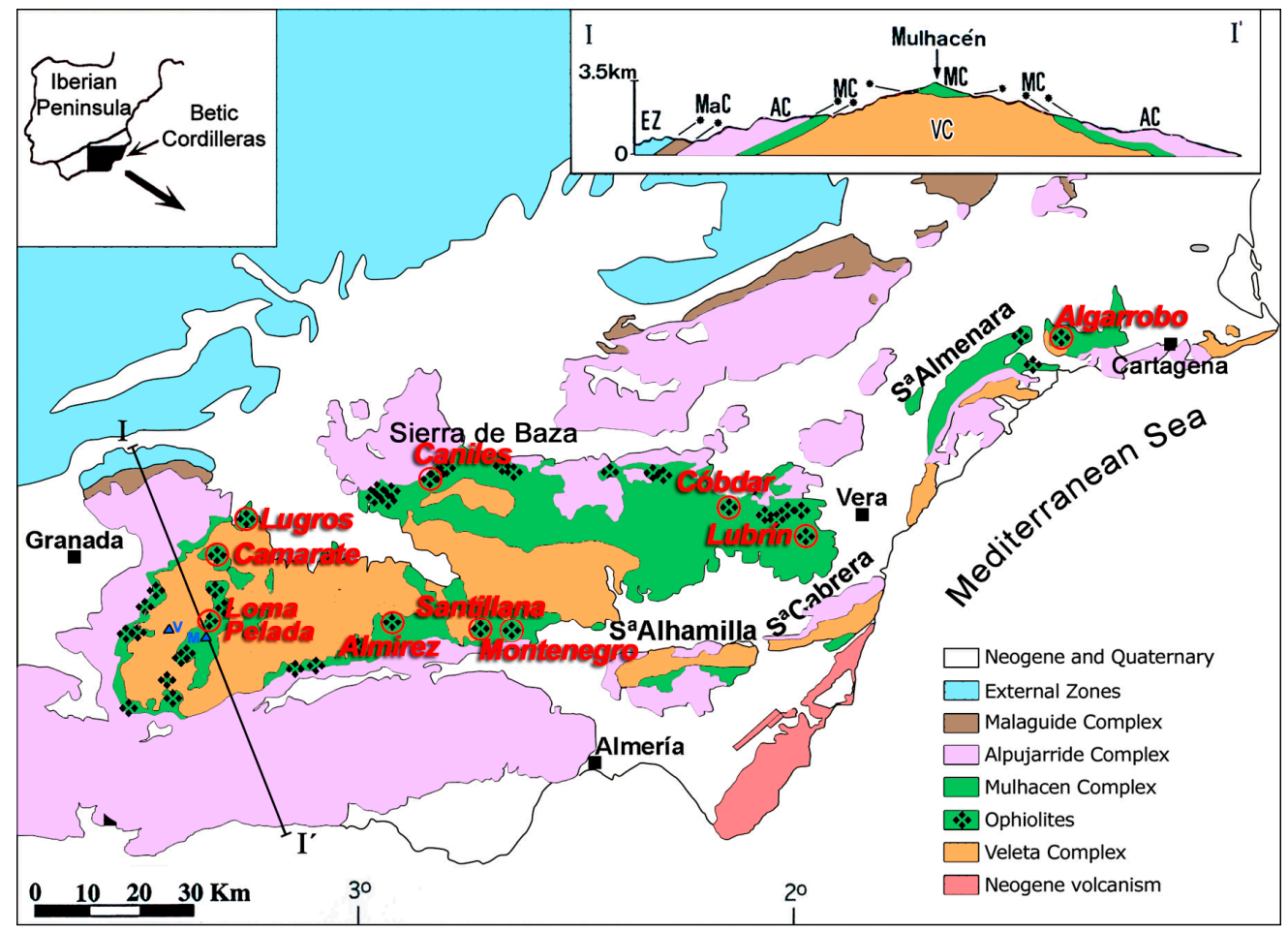

Figure 1. Geological sketch map of the central-eastern sector of the Betic Cordilleras, showing the relationships between the Veleta, Mulhacén and Alpujárride metamorphic complexes and the post-orogenic volcanic and sedimentary formations, modified from Figure 1 in Puga et al. [19]. The upper inset shows a simplified version of the present tectonic relations of the Nevado-Filábride complexes, with Veleta (VC) beneath and Mulhacén (MC) on top, on which the Alpujárride (AC) and Maláguide (MaC) complexes and the External Betic Zones (EZ) are superposed. Black four-pointed stars represent the largest outcrops of the BOA located along the MC of the Nevado-Filábride Domain. Red encircled stars indicate the location of the main ophiolitic outcrops from which most of the studied rocks, considered in this revision, derive. The studied outcrops are the following sites: Lugros, Camarate, Loma Pelada, Almirez, Santillana and Montenegro (in Sierra Nevada), Cóbdar and Lubrín (Sierra de Filabres), Algarrobo (Sierra del Algarrobo) and Caniles (Sierra de Baza). Letters V and M in blue, in the western area of the map, indicate the approximate geographic setting of the Veleta and Mulhacén Pics.

The BOA outcrops, deriving from the betic oceanic floor $[8,13,19]$, allow the reconstruction of the pristine oceanic lithostratigraphy represented in Figure 2, which has been tectonically superimposed on the crustal rocks of its adjoining western continental margin, currently forming the Caldera crustal unit of the MC, and were overthrusted by the rocks deriving from its eastern continental margin, now forming the Sabinas crustal unit (Figure 2). Each of these crustal units consists of rocks deriving from a Paleozoic basement with abundant granitic and rhyolitic orthogneisses, covered by Triassic sediments $[13,16,37,38,41,42]$ and, together with the Jurassic-Cretaceous Ophiolite Unit, constitute the MC. Figure 2 also shows, in its legend, the main lithologic differences existing between the Caldera and the Sabinas units, as well as the more notable differences characterizing the currently underlying $\mathrm{VC}$ by respect to the overlying MC, and their different tectonic units $[13,23]$. 


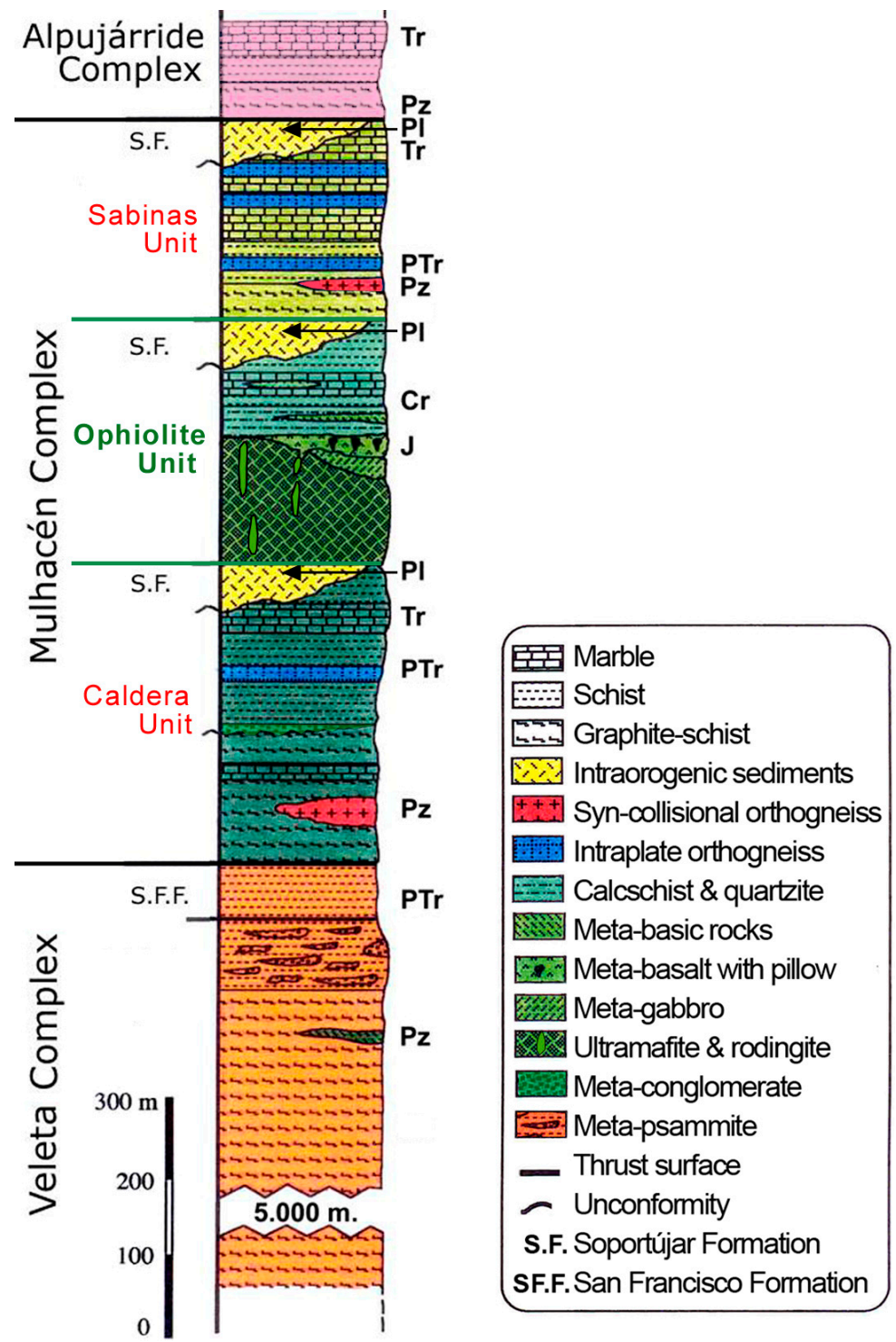

Figure 2. Simplified lithostratigraphic column showing the main rock types of the different tectonic units and formations making up the Veleta and Mulhacén Complexes, together with the lithostratigraphy (not to scale) of the overlying Alpujárride Complex, modified from Puga et al. [19]. The main lithologies forming the different tectonic units and formations are represented in Figure 2 by different screens and colors, whose meaning can be seen in the legend of this figure. Abbreviations on the right border of Figure 2 have the following meaning, Pz: Palaeozoic, PTr: Permian-Triassic, T: Triassic, J: Jurassic, Cr: Cretaceous, Pl: Paleocene, and indicate the radiometrically dated ages, or the geologically more probable ages.

The reconstruction of the primitive relationship of the different rock types forming the Ophiolite Unit on the oceanic floor is mainly based on the present mutual location among the rocks forming the different outcrops of the metamorphosed and dismembered ophiolitic relics, and also by the absolute ages of many dated rocks presented in Table 1 . The main rock types forming the Ophiolite Unit in the lithostratigraphic reconstruction shown in Figure 2 are, from bottom to top: Serpentinites, intruded by rodingitized dolerite dykes, eclogitized and amphibolitized gabbros, dolerite dykes and basalts. These rock types may be found covered by a metasedimentary sequence in which the intercalation of amphibolitized dolerite sills is common, probably partly deriving from thin basaltic levels. 


\section{Petrology and Metamorphic Evolution}

The rocks included in the BOA lithostratigraphy are reported in Figure 2 as located in the original oceanic lithosphere, before being affected by Alpine tectonic activity sensu lato, and the more representative lithologies are illustrated in Figure 3a-c. These figures show the rocks on the outcrops, as well as their microscopic views, also specifying the outcrops of provenance of the different photos.
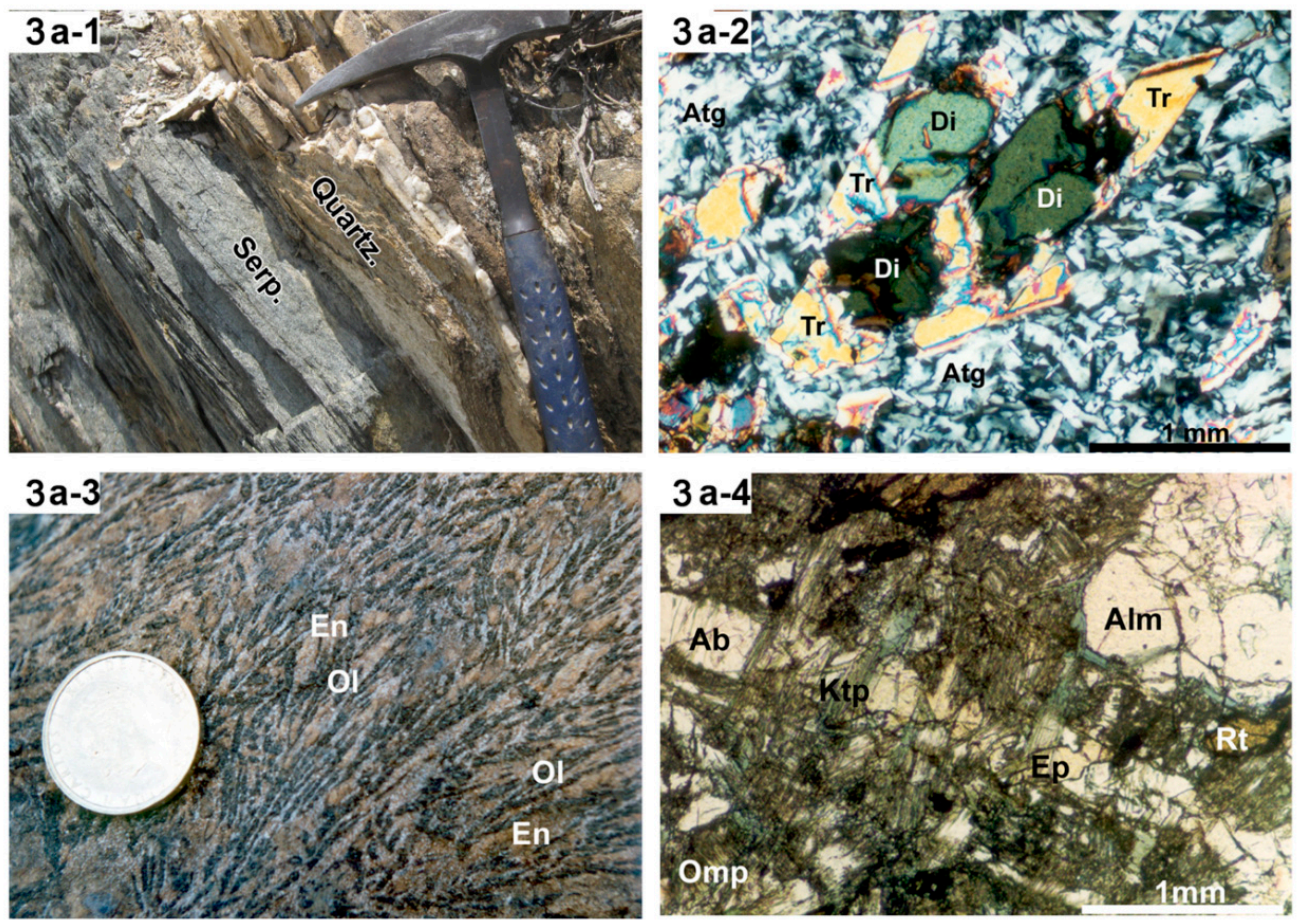

(a)
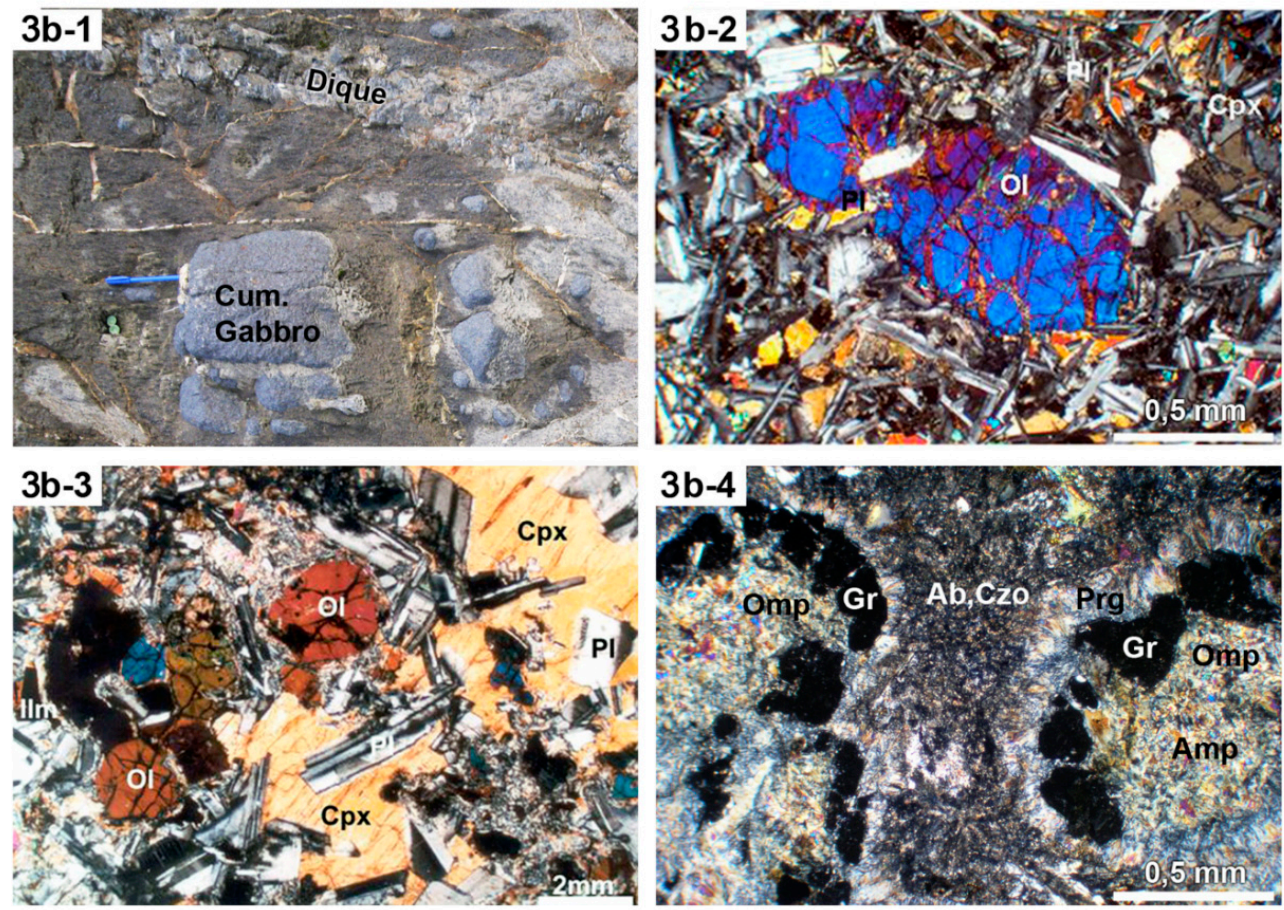

(b)

Figure 3. Cont. 

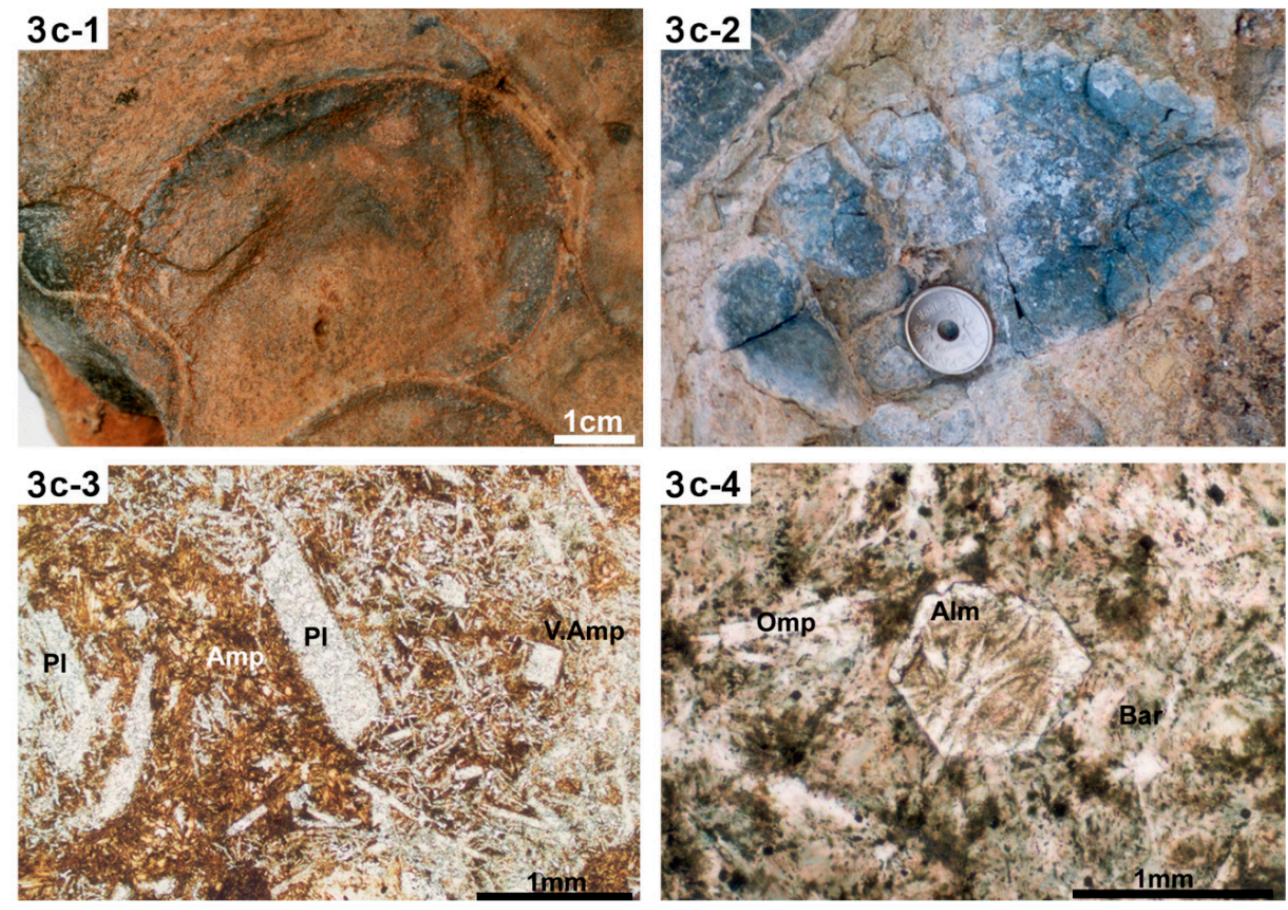

(c)

Figure 3. Main litohlogies forming the ultramafic, plutonic and volcanic sequences of the BOA outcrops: (a) Representative lithologies of the suboceanic mantle sequence: (1) Serpentinites (Serp) and overlying quartzites (Quartz.); (2) microscopic view of serpentinite; (3) secondary spinifex-like harzburgite; (4) microscopic view of eclogitized dolerite dyke. Almirez outcrop. (b) Representative lithologies of the intrusive sequence: (1) Troctolitic gabbro intruded by doleritic dykes; Microscopic view of: (2) olivine gabbro, (3) pyroxene-olivine gabbro and (4) coronitic eclogite. Cóbdar and Algarrobo outcrops. (c) Representative lithologies of the volcanic sequence: (1) Accumulation of eclogitized minipillows, (2) amphibolitized pillow lavas with radial disjunction surrounded by basaltic matrix. Microscopic view of: (3) amphibolitized porphyric basalt, (4) eclogitized pillow basalt. Lugros and Cóbdar outcrops.

Figure 3a represents the main lithologies of the ultramafic sequence, which are serpentinized spinel lherzolites, containing antigorite (Atg), diopside relics (Di) and neoformed tremolite (Tr) (Figure 3a-2). This rock-type presents gradual transition to metamorphic rocks consisting of acicular aggregates of olivine $(\mathrm{Ol})$ and enstatite $(\mathrm{En})$, with pseudo-spinifex texture, known as secondary harzburgites (Figure 3a-3). Both types of ultramafites contain numerous rodingitized and/or eclogitized boudinaged dykes (Figure 3a-4). Thin section microscopic view of a dolerite dyke transformed into eclogite, which is formed by almandine (Alm) omphacite (Omp) and rutile (Rt) paragenesis, partially amphibolitized with development of albite (Ab), epidote (Ep) and kataphoritic amphibole (Ktp). These rocks, of the mantle sequence, can be found directly overlayered by rocks of the sedimentary sequence (Figure 2), formed by near pure quartzites, probably deriving from radiolarites (Figure 3a-1), and/or tourmaline-rich micaschists and calc-schists. The reported photos correspond to rocks from the Almirez outcrop, but similar litohologies are found in the Santillana and Montenegro outcrops [10] (Figure 1).

Figure $3 \mathrm{~b}$ corresponds to cumulitic troctolites and gabbros, intruded by dolerite dykes (Figure $3 b-1$ ), mainly preserving the plutonic structures and locally also the igneous paragenesis (Figure 3b-2,b-3), but more commonly transformed into coronitic eclogites, partly retrograded to amphibolites (Figure 3b-4). Figure 3b-2,b-3 show the local preservation at thin-section scale of igneous olivine $(\mathrm{Ol})$, augitic clinopyroxene $(\mathrm{Cpx})$ and calcic-plagioclase $(\mathrm{Pl})$. Figure $3 \mathrm{~b}-4$ shows a coronitic 
eclogite originated from a cumulitic gabbro. In this metamorphic rock the igneous olivines have been pseudomorphosed by a garnet corona (Gr) surrounding an aggregate of omphacite (Omp) and amphibole (Amp), whereas the igneous plagioclases have been pseudomorphosed by an aggregate of albite $(\mathrm{Ab})$ and clinozoisite (Czo). The preservation of some minerals of the igneous paragenesis, despite the later orogenic metamorphism is recognized only at thin section scale, and mainly in some outcrops like that of Cóbdar where eclogitization was less pervasive than in other sites, like that of Algarrobo where coronitic eclogites are very common (Figure 3b-4).

Figure $3 \mathrm{c}$ represents well preserved pillow structures in basaltic lithologies characterized by different degrees of alpine deformation (Figures 2 and 3c-1). The igneous parageneses are locally replaced by brown amphibole formed during oceanic-floor metamorphic processes (Figure 3c-3) or, more commonly, by the Eo-Alpine eclogitic parageneses partly retrograded to Meso-Alpine amphibolites (Figure 3c-4). In some basaltic levels the effects of the ocean-floor metamorphism has been locally well recorded by high temperature Ti-pargasite (Ti-Prg) brown amphibole (Figure 3c-3) in the groundmass and in millimetric veins, as observed in metabasalts from Cóbdar. Noteworthy, brown amphibole from veins of the Cóbdar metabasalts were dated with Ar-Ar laser probe, indicating a Jurassic age for the oceanic-floor metamorphic process (Table 1).

The Lugros outcrop (Figure 1) shows the best examples of preservation of igneous structures, such as pillows and lava flow-structures despite the complete transformation of the igneous paragenesis into eclogite facies paragenesis. In particular, Figure 3c-1 represents a good example of a minipillows aggregate in which the volcanic structure has been exceptionally well preserved, despite the complete eclogitization of the igneous paragenesis, as shown in Figure 3c-4. This microscopic photo shows a well preserved igneous variolitic texture, formed by a fibrous aggregate of volcanic plagioclase microcrystals later included in an almandinic garnet poeciloblast (Alm), which together omphacite (Omp) and barroisite (Bar) forms the eclogite paragenesis and its later local amphibolitization.

A more detailed petrographic description of the different BOA lithotypes forming the investigated outcrops were reported by Puga et al. [9-11,14,40] and Ruiz Cruz et al. [21].

Both intrusive and volcanic basic rocks are locally covered by an oceanic meta-sedimentary sequence, similar to that previously described onto the ultramafic rocks, as shown in Figure 2. In this metasedimentary sequence calc-schists with centimetric ankerite nodules and some decimetric alternances of marbres and amphibolite sills are very common. Some relics of foraminifer probably cretaceous in age were found by Tendero et al. [39] into the calc-schists of the Cóbdar outcrop. Worth of note, in the Penninic ophiolite units of the Alps, ankeritic nodules similar to those observed in the BOA sedimentary sequence have also been interpreted as Cretaceous planktonic foraminifera, and have been used to establish the chronostratigraphy of metamorphic successions such as the "Schistes lustres" by Lemoine et al. [43] and Lagabrielle et al. [44].

On the whole, the metamorphic evolution inferred from the study of the igneous and sedimentary lithotypes constituting the Betic Ophiolites, together with the radiometric dating of some of their minerals, allow us to deduce their complex pressure-temperature-time evolution as schematized in Figure 4.

The range of ages corresponding to the different metamorphic events shown in Figure 4 can be seen in [13] and in Table 1 of this paper, and summarized as follows:

(a) Ocean floor metamorphism and metasomatism induced serpentinization stage of the ultramafic rocks and rodingitization of the intruded doleritic dykes (Puga et al. [10,17,19]; Alt et al. [22]). It also produced paragenesis of very high gradient in amphibolite facies, characteristic of ocean floor metamorphism, preserved in some gabbros and basalts $[11,14,21,40]$. The P-T conditions of this oceanic metamorphism and metasomatism, represented in Figure 4, mainly correspond to the range of P-T calculated for the brown amphiboles of the Cóbdar metabasites, shown in Photo 3c-3, by Puga et al. [14].

(b) Orogenic metamorphism, begining with subduction of the ocean floor during an initial metamorphic event known as Eo-Alpine, which attained eclogite facies conditions. This was 
followed by exhumation of part of this subducted ocean floor onto the continental margin, during and after which the Meso-Alpine and Neo-Alpine metamorphic events of Oligocene and Miocene ages took place $[10,11,13,20]$. The successive parageneses of eclogite, Ab-Ep amphibolite and greenschist facies developed during these three metamorphic events, variously overprinting the pristine igneous parageneses and textures $[11,13-15,19,40]$.

The P-T trajectories shown in the upper inset of Figure 4 represent the temporal evolution of the orogenic metamorphism in the BOA, and other MC rocks, from the eclogite facies, with the peak $\mathrm{P}-\mathrm{T}$ conditions approximately represented by M1, which were followed by Ab-Ep amphibolite and greenschist facies conditions, with a peak $\mathrm{P}-\mathrm{T}$ conditions represented by $\mathrm{M} 2$. The more precise $\mathrm{P}-\mathrm{T}$ conditions for the BOA rocks in these successive stages of alpine metamorphism are represented in Figure 4, into the eclogitic fields $\mathrm{M} 1 \mathrm{Ob}$ and $\mathrm{M} 1 \mathrm{Ou}$, for basic and ultramafic rocks, respectively, and into the M2 field showing the conditions for the later partial transformation of eclogites into $\mathrm{Ab}$-Ep amphibolites. A more precise explanation of the reactions selected to delimitate the successive metamorphic field conditions attained in the BOA rocks and in the other units forming part of the MC and VC can be seen in Puga et al. $[10,11,13]$.

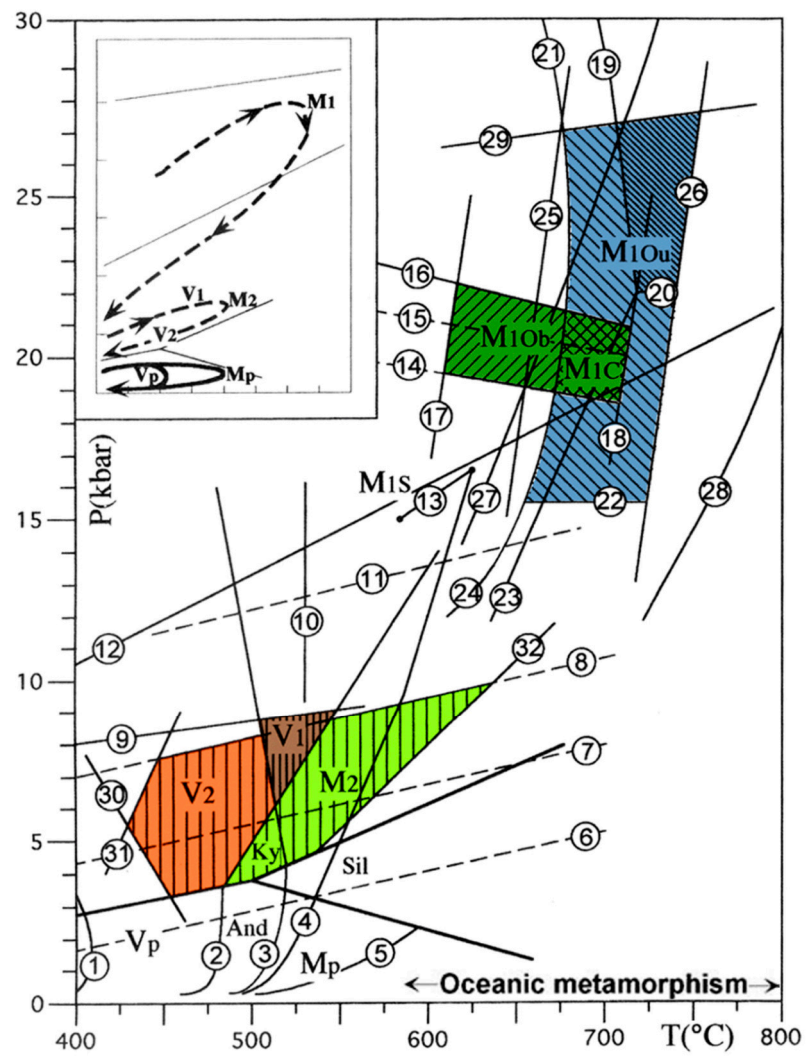

Figure 4. P-T diagram showing the stability fields of the different metamorphic events registered in the BOA (basic and ultramafic rocks) compared with other units of Veleta and Mulhacén complexes, modified from Puga et al. [13]. Meaning of abbreviations indicating these fields are $\mathrm{V}$ and brown color: Veleta; M and green or blue color: Mulhacén; P: Pre-Alpine; 1: Eo-Alpine; 2: Meso-Alpine and Neo-Alpine; C: Caldera Unit; S: Sabinas Unit; Ou: Ultramafic rocks of the Ophiolite Unit; Ob: Basic rocks of the Ophiolite Unit. The schematic P-T-t path in the inset of this figure shows the climax conditions corresponding to the Pre-Alpine, Eo-Alpine and Meso-Alpine events represented, respectively, by the position of Mp, M1 and M2 for the MC, and by those of Vp, V1 and V2 for the VC. The position of the arrow with the label "Oceanic metamorphism" indicates the range of low pressure and high temperature conditions deduced for this process in the Cóbdar metabasalts (Puga et al. [14]). Labeled metamorphic reactions as in Puga et al. [13]. 


\section{Geochemical Characteristics and Tectonic Setting of the BOA Magmas}

The chemical composition of representative rocks from selected outcrops of the Betic Ophiolites are shown in tectono-magmatic diagrams that discriminate the geodynamic context of distinct basaltic magmas, together with the mean compositions of these current magma types from different geodynamic settings for comparison (Figure 5). The symbols for the different types of ophiolitic rocks are explained in the legend of the figure, together with indication of the outcrops location.
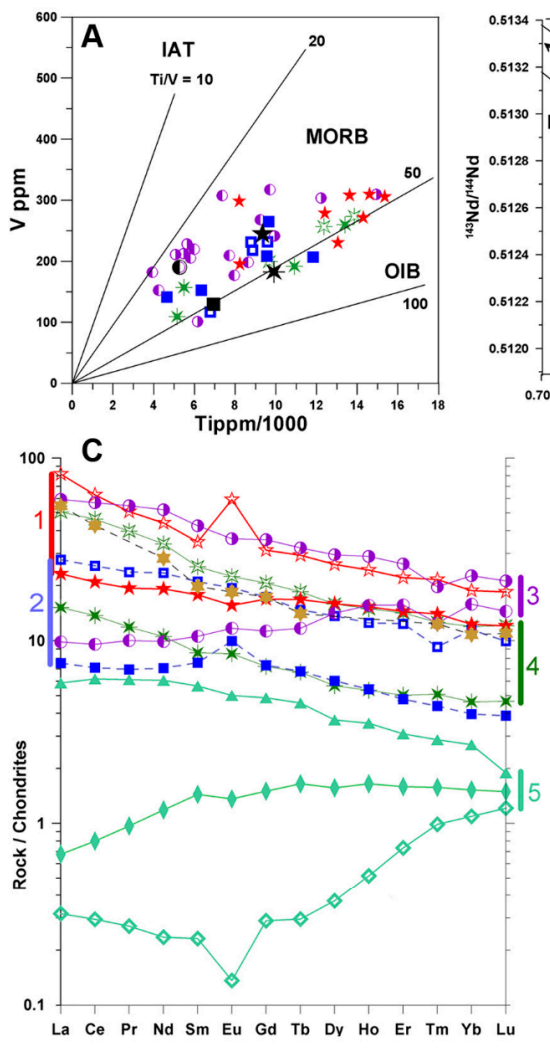

Legend for symbols

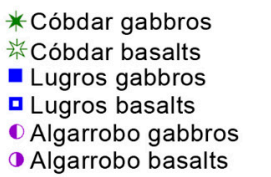

Almirez outcrop:

$\star$ Rodingites

Lherzolitic serpentinites Clinopyroxenites

$\diamond$ Secondary harzburgites

* $\star \star$. Rocks with zircons

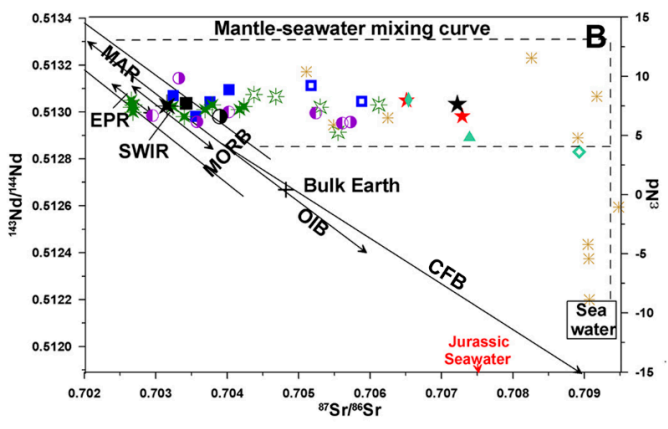

D

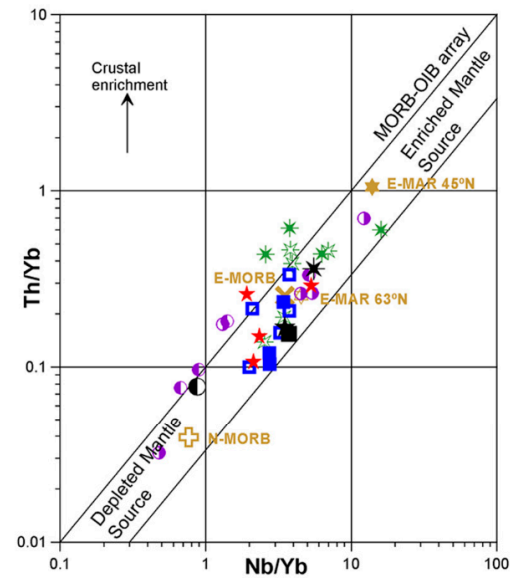

Brown symbols = average values for current oceanic-ridge basalts \& abyssal peridotites

MORB = Mid-oceanic-ridge basalts OIB = Oceanic-island basalts IAT = Island-arc tholeiites MAR = Mid-Atlantic Ridge $E P R=$ Eastern Pacific Rise SWIR= Southwestern Indian Ridge

Figure 5. Distribution of scarcely mobile trace elements (A), or their ratios (D), REE values normalized to chondrites (C) and isotopic ratios of $\mathrm{Sr}$ vs. $\mathrm{Nd}(\mathbf{B})$ of the different lithologies forming the Betic Ophiolites compared with MORB, OIB and IAT basic magmas, modified from [19] in order to include the following outcrops: Cóbdar, Lugros, Algarrobo and Almirez. (A) Ti/1000 vs. V diagram (Shervais [45]); (B) $\mathrm{Nb} / \mathrm{Yb}$ vs. Th/Yb diagram (Pearce [46]); (C) Chondrite-normalised REE diagram for basic and ultramafic rocks, using normalising values of Boynton [47]; (D) $87 \mathrm{Sr} / 86 \mathrm{Sr}$ vs. $143 \mathrm{Nd} / 144 \mathrm{Nd}$ isotope correlation diagram for basic and ultramafic rocks of the Betic Ophiolites, compared with abyssal peridotites (data from Snow et al. [48]); dashed lines showing mantle-seawater mixing curves for the abyssal peridotites are also reported by Snow et al. [48]); Sr and Nd isotopic values for EPR (Eastern Pacific Rise), MAR (Mid-Atlantic Ridge), SWIR (South Western Indian Ridge) and OIB values (Oceanic Island basalts) from Hoffman [49] ; CFB values (Continental flood basalts) from Marzoli et al. [50]. Note that in Figure 5A,B,D, are also plotted, with black color, the rocks radiometrically dated, deriving from each of the four selected outcrops, to show the chemical similarity between the dated rocks and the other rocks from the same outcrops. 
In spite of metamorphism, geochemical tracers such as rare earth and high field strength elements (REE, HFSE) still provide useful information on the original tectono-magmatic setting. BOA rocks show geochemical analogies with ophiolites from the Alps and the Apennines, whereas they differ from ophiolites widespread in the eastern Mediterranean, where supra-subduction affinities have been recorded [25,51,52].

Comparison in Figure 5A-D of the BOA magma compositions with those corresponding to the current magmas from different tectonic setting, indicate that the geochemical affinity of the different types of basic rocks in the Betic Ophiolites is mainly E-MORB or T-MORB, and locally N-MORB only for the case of magmas from Algarrobo outcrop (Figure 5C,D).

The basic rocks forming all the studied Betic Ophiolites outcrops, represented in Figure 1, are derived from Ti-rich tholeiitic magmas (Figure 5A). This magmatic affinity is characteristic of Ti-rich ophiolites, derived from oceanic floor created on oceanic ridges far from subduction zones (Beccaluva et al. [25]).

Most of the basic rocks from the Betic Ophiolites plotted in Figure 5C,D are consistent with the E-MORB average value of Sun and McDonough [53], and with the present-day volcanism at $63^{\circ} \mathrm{N}$, and less commonly at $45^{\circ} \mathrm{N}$, on the Mid-Atlantic Ridge. The enrichment in Th/Yb presented by some samples in Figure 5D, especially in rocks from Cóbdar and Algarrobo outcrops, can be related to assimilation of the thinned and rifted crustal rocks preexisting to the opening of the Betic Ocean, or to interaction with crustal rocks located at the continental margin. Tholeiitic magmas similar to those that formed the Betic Ophiolites are typical of slowly expanding oceanic ridges, especially in the initial stages of oceanization, when embryonic ridges evolve after continental breakup, i.e., during a transition between rifting and drifting before the attainment of a steady-state spreading regime, and therefore may be classified as "Continental margin ophiolites" according to the classification of $[30,33]$ and Pearce [54] classification.

The geochemical and petrological characteristics of the Betic Ophiolites suggest an ultraslow-spreading ridge environment, similar to that hypothesized by Piccardo [55] for the Jurassic Ligurian Tethys. In fact, the current ultraslow ridges (such as the Gakkel Ridge in the Arctic region and the Southwest Indian Ridge) are typically characterized by relatively scarce and episodic magmatic activity, mainly originating in T- to E-MORB melts forming the "magmatic segments" distinguished by the abundance of basic rocks, linked by "amagmatic segments" in which serpentinized peridotite is the predominant lithology (Dick et al. [32]; Michael et al. [56]). This alternance of predominant basic and ultramafic rocks along the current ultra-slow ridges is similar to that characterizing the lithologies found in the Betic ophiolitic outcrops, along their extension of about $250 \mathrm{~km}$ in the Mulhacén Complex (Figure 1), despite the fact that the Betic oceanic-floor was subducted and subsequently exhumed onto the continental margin and, consequently, tectonically dislacerated during orogenic processes.

The enrichment of the BOA basic rocks in incompatible trace elements generating a predominant E-MORB and T-MORB character, by respect to N-MORB, could in theory be related to mantle sources activated by upraising mantle plumes comparatively enriched in trace elements (Gale et al. [34]; Herbrich et al. [35]), but in our view, for the BOA study case, is more likely attributed to magma genesis by (1) relatively low melting degree; and (2) associated with metasomatized lithospheric mantle sources. These inferences are perfectly compatible with both an OCT setting and an ultraslow-spreading ridge environment (see discussion below), where mantle sources were not depleted by prolonged magmatism.

The broad isotopic variation of the ${ }^{87} \mathrm{Sr} /{ }^{86} \mathrm{Sr}$ ratio in the Betic Ophiolites (Figure 5B) can be explained by the different degrees of metasomatism undergone by the basic and ultramafic rocks at the ocean floor. This process affected more intensively the basalts than the gabbros of each one of the studied outcrops (Lugros, Cóbdar and Algarrobo) and, in higher degree, the ultramafic rocks and their hosted dolerite dykes, which attained the highest $\mathrm{Sr}$ isotopic ratios, typical of Jurassic water (0.7072-0.7075, Jones et al. [57]), during their oceanic metasomatism, originating the rodingitisation and the coeval serpentinisation process [10]. Similarly, abyssal peridotites from current oceanic fracture 
zones (plotted in Figure 5B) also show an increase in ${ }^{87} \mathrm{Sr} /{ }^{86} \mathrm{Sr}$ isotope values due to contamination by present-day seawater $\left({ }^{87} \mathrm{Sr} /{ }^{86} \mathrm{Sr}=0.7092\right.$; Snow et al. [48]), which also affected this isotopic ratio for some of the Almirez serpentinites plotted in the same diagram.

Concluding, in our view the geochemical characteristics of the Betic Ophiolites are similar to those forming some of the outcrops of the Alpine-Apennine ophiolitic chain, which also derive from the Jurassic oceanic floor of the Western Alpine Tethys $[19,25,58,59]$.

\section{Radiometric Dating of the BOA}

A relevant contribution of our researches has been the dating of the BOA rocks through the U-Pb isotopic analyses of zircons. These crystals although rare in the oceanic-floor basic rocks, have been separated from selected samples by processing about 20-30 kg of material from each sample. Note that in this contribution we preliminarily present some new igneous dating on zircons from rocks collected in the localities of Cóbdar and Algarrobo. These radiometric data implement those presented by Puga et al. [15,19] on rocks from the localities of Lugros and Almirez (Figure 1).

The cathodoluminescence images (CL) of four selected zircons from Lugros, Cóbdar, Algarrobo and Almirez outcops, are shown in Figure 6. The CL photos show three main microstructures in the studied zircons: (i) some crystals with idiomorphic rims and oscillatory zoning, which indicate the igneous origin of the zircon domains, together with (ii) locally recrystallized domains, which do not preserve the oscillatory zoning, probably due to oceanic-floor recrystallization processes, and (iii) crystal sectors presenting whitish color and clouded irregular forms that surround small rounded empty spaces (black in the CL photos). The latter bright and irregular crystal domains have been interpreted (by Puga et al. $[15,19]$ ) as developed during a fluid-assisted recrystallisation process of the zircon areas originally surrounding micropores that were previously filled by fluid inclusions. In the zircon crystal from Lugros (Figure 6A) these recrystallized whitish areas yield an age of Upper Cretaceous $(83.7 \pm 1 \mathrm{Ma})$, while the oscillatory zoned rim of the same crystal yield an igneous age of Lower Jurassic (189.4 $\pm 2.2 \mathrm{Ma})$; in the Almirez zircon crystal (Figure 6D), with igneous age of $186.7 \pm 2 \mathrm{Ma}$, the recrystallysed area, surrounding a micropore, yield a Paleocene age (59.2 $\pm 0.8 \mathrm{Ma})$. This range of recrystallization ages from Upper Cretaceous to Paleocene would correspond to the Eo-Alpine metamorphic stage, which affected these rocks in eclogite facies conditions, during the subduction of the oceanic floor from which the Betic Ophiolites derive (Table 1).

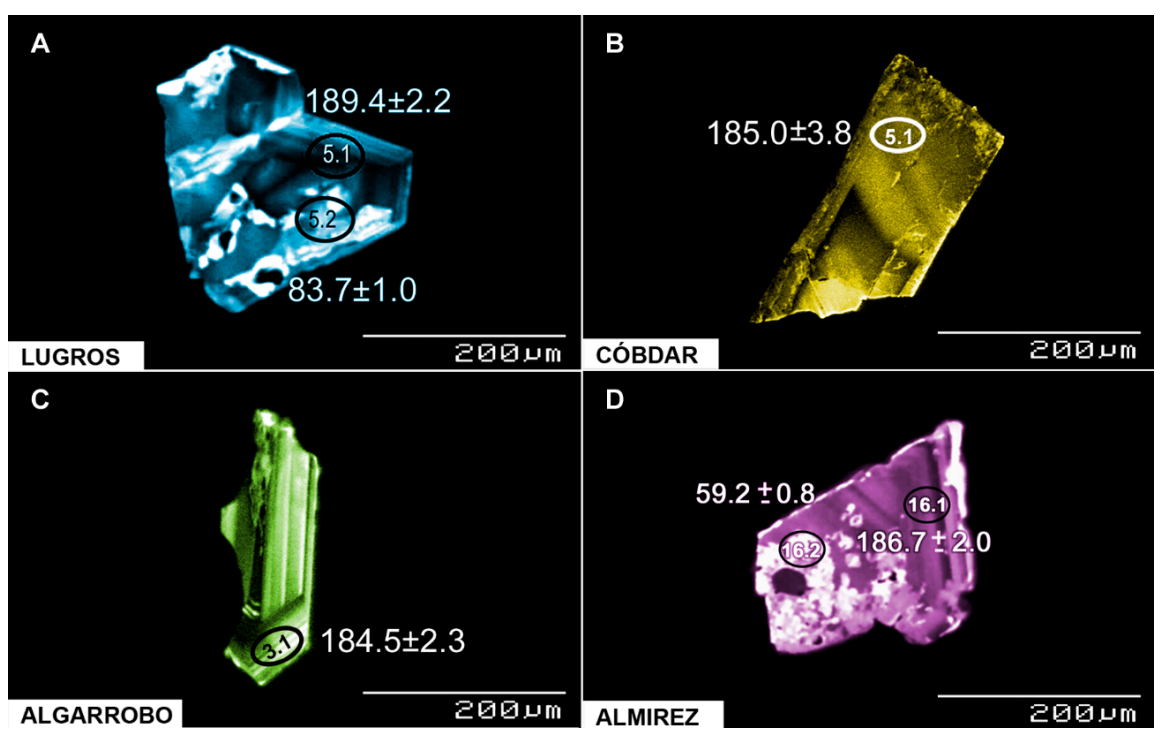

Figure 6. Cathodoluminescence images of selected zircons of BOA eclogitized gabbros and dolerites from the representative outcrops of Lugros, Cóbdar, Algarrobo and Almirez dated by $\mathrm{U} / \mathrm{Pb}$ with SHRIMP (Sensitive High Resolution Ion Micro-Probe). 
The Lugros eclogite histogram, Figure 7A, shows the average age corresponding to the Pliensbachian $(187.4 \pm 2.5 \mathrm{Ma})$, as well as a series of ages interpreted as corresponding to oceanic-floor recrystallisation between about 165 and $130 \mathrm{Ma}$, and Eo-Alpine metamorphic ages, comprised between 90 and $55 \mathrm{Ma}$. These latter ages are better represented in Lugros than in the partly eclogitized gabbros from Códar (Figure 7B) and Algarrobo (Figure 7C) outcrops, that were less pervasively recrystallized after their igneous crystallization (Figure 3b-2,b-3). The histogram of the dolerite dyke from Almirez outcrop (Figure 7D) shows, together with the Pliensbachian crystallisation age (with average value of $183.9 \pm 1.6 \mathrm{Ma}$ ), another subordinate peak (with average age of $177.5 \pm 2.0 \mathrm{Ma}$ ), corresponding to the more luminescent discontinuous rim of their zircons (Figure 6D), which is interpreted as the overgrowth of the igneous crystals during the oceanic rodingitisation process, as well as other recrystallization ages, about 170-150 Ma, which must correspond to the Upper-Middle Jurassic oceanic-floor metasomatism which strongly affected the ultramafic rocks and their hosted dolerite dykes. In this rock the Paleocene Eo-Alpine metamorphism, which is suggested by Figure 6D, is not registered in the histogram of Figure 7D. However, the complex evolution history, recorded by zircons of dolerite dykes intruded in the Almirez ultramafic rocks, which were rodingitized and later locally eclogitized, has been also delineated by the stable isotopes investigation of the hosting serpentinites (Alt et al. [22]).

It is important to note that all the dated rock types yielded, for the oscillatory zoned areas of their zircons, a common average magmatic age around $185 \mathrm{Ma}$ ([15,19]; Figure 7 and Table 1). This age is interpreted as the beginning of the oceanic crust development for the gabbros forming the basal layer of Lugros, Cóbdar and Algarrobo outcrops, and as the age of intrusion of the dolerite dykes into the ultramafic rocks forming the Almirez outcrop.

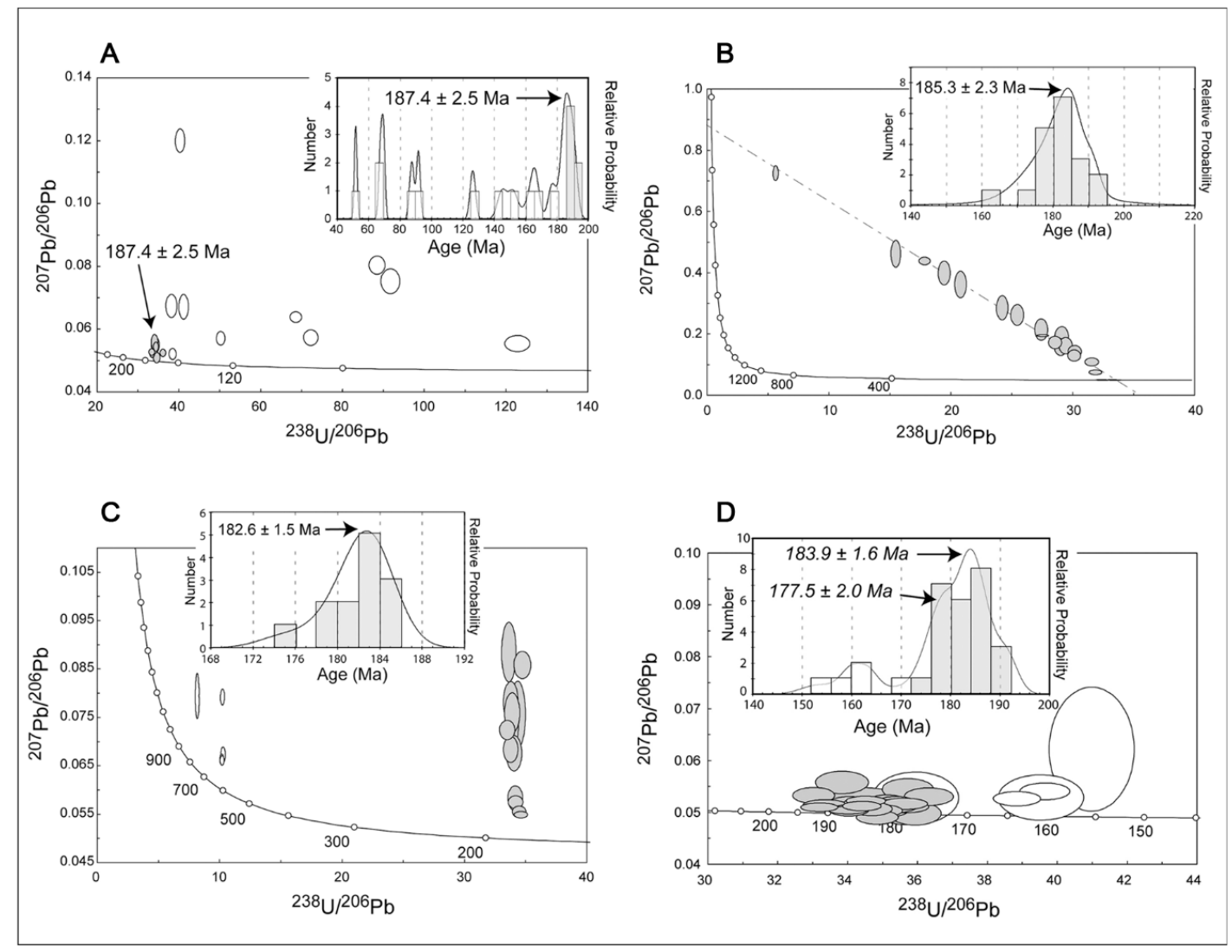

Figure 7. Tera-Wasserburg diagrams and probability histograms with mean ages for the dated zircons of four samples from Lugros (A), and Almirez (D) outcrops, according to [19], complemented with samples from Cóbdar (B) and Algarrobo (C). 
The $\mathrm{U} / \mathrm{Pb}$ radiometric dating by SHRIMP of distinct zircon domains distinguished in the studied zircons allowed us to determine with precision an igneous Lower Jurassic age, in the range of 190 to $180 \mathrm{Ma}$, with average age of $185 \mathrm{Ma}$, likely representing the beginning of the oceanic magmatism (Figures 6 and 7). Other groups of ages, although not as well defined, correspond to Lower to Middle Jurassic age, probably corresponding to ocean-floor metamorphism and metasomatism, and between the Upper Cretaceous to Paleocene, corresponding to the first orogenic Eo-Alpine recrystallization process that took place during the subduction and eclogitization of the oceanic floor (see Table 1). These two stages of recrystallization of the igneous zircons have not been ubiquitously developed, and/or preserved, in all the samples after to have undergone the Meso-Alpine and Neo-Alpine metamorphic events. They have been better preserved in the zircons from Lugros and Almirez outcrops as is shown in Figures 6 and 7 and mainly in Puga et al. [15,19].

The oceanic-floor metamorphism has been also well preserved in the brown amphibole (Ti-pargasite and Kaersutite) filling little veins in ophiolitic metabasites, which has been dated by ${ }^{40} \mathrm{Ar} /{ }^{39} \mathrm{Ar}$ laser probe as Middle Jurassic (Puga et al. [60]). Moreover, the glaucophane crystals formation, present in the last stage of some eclogites development [11], could correspond to the exhumation process of some oceanic floor slabs onto the continental margin. The crystallization of this Na-amphibole has been dated as near to $70 \mathrm{Ma}$ by the K/Ar method in a Cóbdar amphibolite (Portugal Ferreira et al., [61]). The following metamorphic events, corresponding to the Meso-Alpine and Neo-Alpine stages, identified in BOA and in other Nevado- Filábride units, have produced scarce recrystallization in the zircons of the ophiolitic metabasites, although they have been radiometrically dated, mainly by Ar/Ar and K/Ar methods, corresponding to Eocene-Oligocene and Miocene ages, respectively (Table 1).

The most characteristic minerals developed during the Meso-Alpine metamorphism, in Ab-Ep amphibolite facies conditions, are the Na-Ca amphiboles, which replace the omphacite, garnet and glaucophane of the eclogitic paragenesis and, more locally, the high gradient brown amphibole relics formed during the Middle-Upper Jurassic ocean-floor metamorphic stage [11,13,14,60]. These Na-Ca amphiboles have been dated by the Ar/Ar method between 50 and $40 \mathrm{Ma}$ in partly amphibolitized eclogites (Monié et al. [62]; Puga et al. [13]). Other minerals of this same metamorphic event are the phengitic micas and the Fe-Mg amphiboles, which have been dated by $\mathrm{Ar} / \mathrm{Ar}$ and $\mathrm{K} / \mathrm{Ar}$ methods between 30 and $25 \mathrm{Ma}[13,61,62]$. This range of Meso-Alpine absolute ages include some of the $\mathrm{U} / \mathrm{Pb}$ ages obtained on recrystallized zircon domains, especially in the Lugros eclogites (Puga et al. [15]).

Finally, the Neo-Alpine metamorphic event, developed mainly in greenschists facies conditions in all the units forming the Nevado-Filábride Complexes, has been dated beetwen 15 and $10 \mathrm{Ma}$. on different minerals and by different methods (Table 1). White micas and Fe-Mg amphiboles of amphibolitized eclogites and rodingites from several ophiolitic outcrops were dated by Ar-Ar and K-Ar as crystallized from 11 to 13 Ma. (Portugal Ferreira et al. [61]; Puga et al. [13], and zircon from a pyroxenite boudin, hosted by serpentinite from Almirez, was dated as $15 \mathrm{Ma}$. (López Sanchez-Vizcaíno et al. [63]). These later authors considered the dated zircons as formed during a Miocene high-pressure metamorphism meanwhile a discussion against this interpretation may be found in Puga et al. [15], pp. 197-198.

Table 1. Radiometric dating of the different genetic processes originating from the Betic Ophiolites.

\begin{tabular}{|c|c|c|c|c|}
\hline Type of Sample & Locality & Method & Closing Age (Ma) & Reference \\
\hline \multicolumn{5}{|c|}{ Jurassic magmatism } \\
\hline Oscillatory zoned zircon in eclogitized gabbro & Lugros & SHRIMP U-Pb & $186.5 \pm 2.5$ & Puga et al. [15] \\
\hline Oscillatory zoned zircon in eclogitized rodingite & Almirez & SHRIMP U-Pb & $183.9 \pm 1.6$ & Puga et al. [19] \\
\hline Oscillatory zoned zircon in eclogitized gabbro & Cóbdar & SHRIMP U-Pb & $185.3 \pm 2.4$ & This paper \\
\hline Oscillatory zoned zircon in eclogitized gabbro & Algarrobo & SHRIMP U-Pb & $182.6 \pm 1.4$ & This paper \\
\hline Biotite relic in gabbro & Lubrín & $\mathrm{Ar} / \mathrm{Ar}$ & $173.2 \pm 6.3$ & De Jong $[64]$ \\
\hline Olivine dolerite mineral isochrone & Lubrín & $\mathrm{Rb} / \mathrm{Sr}$ & $146 \pm 3$ & Hebeda et al. [65] \\
\hline
\end{tabular}


Table 1. Cont.

\begin{tabular}{|c|c|c|c|c|}
\hline Type of Sample & Locality & Method & Closing Age (Ma) & Reference \\
\hline \multicolumn{5}{|c|}{ Ocean-floor metamorphism } \\
\hline Brown amphibole veins in metabasalt & Cóbdar & $\mathrm{Ar} / \mathrm{Ar}$ laser & $158 \pm 4.5$ & Puga et al. [60] \\
\hline Non-zoned recrystallized zircon areas in eclogite & Lugros & SHRIMP U-Pb & $155 \pm 2.7$ & Puga et al. [19] \\
\hline Overgrowth rim on rodingite igneous zircon & Almirez & SHRIMP U-Pb & $177.5 \pm 2$ & Puga et al. [19] \\
\hline \multicolumn{5}{|c|}{ Eo-Alpine event } \\
\hline Clouded whitish zircon areas in eclogite & Lugros & SHRIMP U-Pb & $80.4 \pm 1.4$ & Puga et al. [15] \\
\hline Clouded whitish zircon areas in eclogite & Lugros & SHRIMP U-Pb & $73.5 \pm 1.1$ & Puga et al. [19] \\
\hline Clouded whitish zircon areas in rodingite & Almirez & SHRIMP U-Pb & $59.2 \pm 0.8$ & Puga et al. [19] \\
\hline \multicolumn{5}{|c|}{ Meso-Alpine event } \\
\hline Barroisitic amphibole in retrograded eclogite & $\mathrm{S}^{\mathrm{a}} \mathrm{Baza}$ & $\mathrm{Ar} / \mathrm{Ar}$ & $48.4 \pm 2.2$ & Monié et al. [62] \\
\hline \multicolumn{5}{|c|}{ Neo-Alpine event } \\
\hline Metamorphic zircon in pyroxenite & Almirez & SHRIMP U-Pb & $15 \pm 0.6$ & Lopez Sánchez-Vizcaino et al. [63] \\
\hline White mica in simplectitized amphibolite & Cauchiles & $\mathrm{Ar} / \mathrm{Ar}$ & $13 \pm 1.5$ & Puga et al. [13] \\
\hline Paragonite in amphibolite & Camarate & $\mathrm{Ar} / \mathrm{Ar}$ & $12.4 \pm 1.1$ & Puga et al. [13] \\
\hline Actinolite in amphibolitized rodingite & Almirez & $\mathrm{K} / \mathrm{Ar}$ & $11 \pm 3$ & Portugal Ferreira et al. [61] \\
\hline Actinolite in amphibolite & Camarate & $\mathrm{Ar} / \mathrm{Ar}$ & $11 \pm 0.9$ & Puga et al. [13] \\
\hline
\end{tabular}

\section{Comparison of the Betic Ophiolites Radiometric Dating with Those of Alpine-Apenninic Ophiolites}

The MOR-type ophiolites found at different locations in the Alps and Apennines (Figure 8) were dated using different radiometric techniques, of which the most reliable for inferring the age of magmatism are $\mathrm{Sm} / \mathrm{Nd}$ and especially $\mathrm{U} / \mathrm{Pb}$ applied to zircons from gabbros, complemented with dating of radiolarians preserved in the sedimentary sequences of some poorly metamorphosed ophiolites. Figure 8, by Bortolotti and Principi [66], shows the results of this dating and the techniques used on the ophiolites from each location. Some of the radiometric dating of Betic Ophiolites (shown in Table 1), coming from: Lugros, Almirez, Cóbdar and Algarrobo outcrops (Figure 1), which form part of the Ophiolite Unit of the MC, in the Nevado-Filábride Domain, have been also included in Figure 8 as Betic Cordillera for comparison.

As explained in the previous chapters, if we take into account only the dating carried out by $\mathrm{U} / \mathrm{Pb}$ with SHRIMP on zircons, the mean absolute age for the magmatism originating from the Betic oceanic lithosphere ranges from 190 to $180 \mathrm{Ma}$, with an average age close to $185 \mathrm{Ma}$ (Pliensbachian), for previously dated samples from Lugros and Almirez outcrops [15,19]. These ages have been confirmed by the more recent dating of samples from Cóbdar and Algarrobo outcrops, shown in Figures 6 and 7 and Table 1 of this paper, whereas the SHRIMP U-Pb ages of gabbroic rocks from the Alps, Corsica and Apennines (with red color in Figure 8) yield comparatively younger ages, beginning at around $165 \mathrm{Ma}$. These Middle-Upper Jurassic ages for igneous zircons in gabbros and plagiogranites from the Alpine-Apennine Ophiolites (Figure 8) are also commonly accepted by other authors (Borsi et al. [67]; Costa and Caby [68]; Rubatto and Scambelluri [69]; Kaczmarek et al. [70]; Manatschal and Müntener [28]) and conform within the chronological interval 165-140 Ma. Thus, according to the SHRIMP zircon dating shown in Figures 6-8, and to the data compilation in Manatschal and Müntener [28], we can conclude that the break-up of Pangea and the development of the Western Tethys oceanic-floor began at the westernmost sector, from which the Betic Ophiolites derive (Betic Tethys) about $20 \mathrm{Ma}$ earlier than in the northeastern extension (Ligurian and Alpine Tethys), from which the Alpine-Apennine Ophiolites originated. 

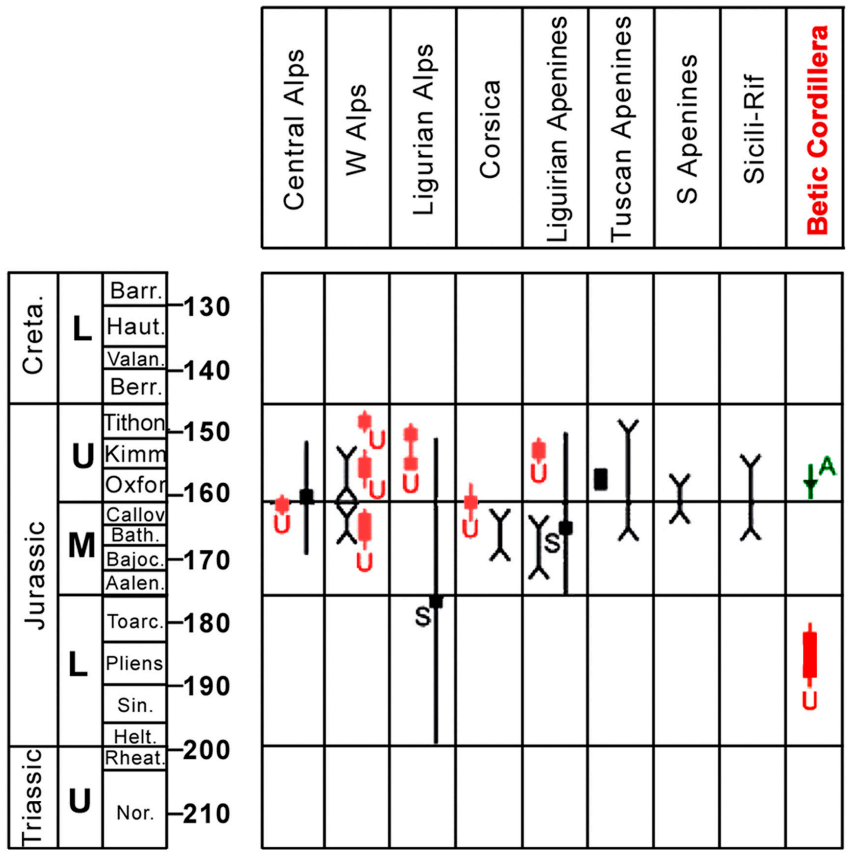

- = gabbroic rocks

$\mathrm{U}=\mathrm{U} / \mathrm{Pb}$

$A=$ amphibole veins in basalts

$\mathrm{S}=\mathrm{Sm} / \mathrm{Nd}$

$Y=$ radiolarians

Figure 8. Comparison of igneous ages between Alpine-Apennine Ophiolites and the Betic Ophiolites from Lugros and Almirez [19], together with those from Cóbdar and Algarrobo outcrops added in this paper. This figure includes the chronological data obtained by different methods on the Alpine-Apennine Ophiolites, deriving from the Jurassic Western Tethys (according to Bortolotti and Principi [66]), complemented by some representative zircons dating from the Betic Ophiolites, shown in Figures 6 and 7, and in Table 1. The comparable SHRIMP U/Pb dating on zircons from Betic and Alpine-Apennine ophiolitic gabbros are all represented with red color for more clarity. In green the Middle Jurassic age is represented, obtained for the oceanic floor metamorphism, applying Ar/Ar laser probe for dating millimetric veins of brown amphibole, which form part of the BOA basalts in the Cóbdar outcrop (Table 1).

\section{Mesozoic Paleogeographic Reconstruction of the Betic Tethys}

The new dating of zircons by SHRIMP for the Cóbdar and Algarrobo outcrops reinforce the hypothesis developed by Puga et al. [15,19], based on zircon dating from Lugros and Almirez outcrops, indicating that an important phase of formation of oceanic crust occurred between 190 and $180 \mathrm{Ma}$, all along the Betic Ocean domain (Figure 1). This suggest that the opening of the Betic sector of the neo-Tethys preceded that of the adjacent Ligurian and Alpine Tethys oceanic domains (Handy et al. [59], Bortolotti and Principi [66], Bill et al. [71]; Tribuzio et al. [72]; Rampone et al. [73]) of at least $20 \mathrm{Ma}$, as is shown in Figure 8.

This observation is important as it implies : (1) that the Betic Ophiolites would be the only preserved relics along the Alpine Chain deriving from the westernmost end of the Tethys, which is Pliensbachian in age as is shown in Figure 9a from Schettino and Turco [74]; and (2) that these ophiolites represent the birth of the westernmost Tethys Ocean and consequently the initial stage of the Pangaea break-up along the Betic Tethys, which was simultaneous to the opening of the Atlantic Ocean between $10^{\circ} \mathrm{N}$ and $20^{\circ} \mathrm{N}$ (Figure 9a). 


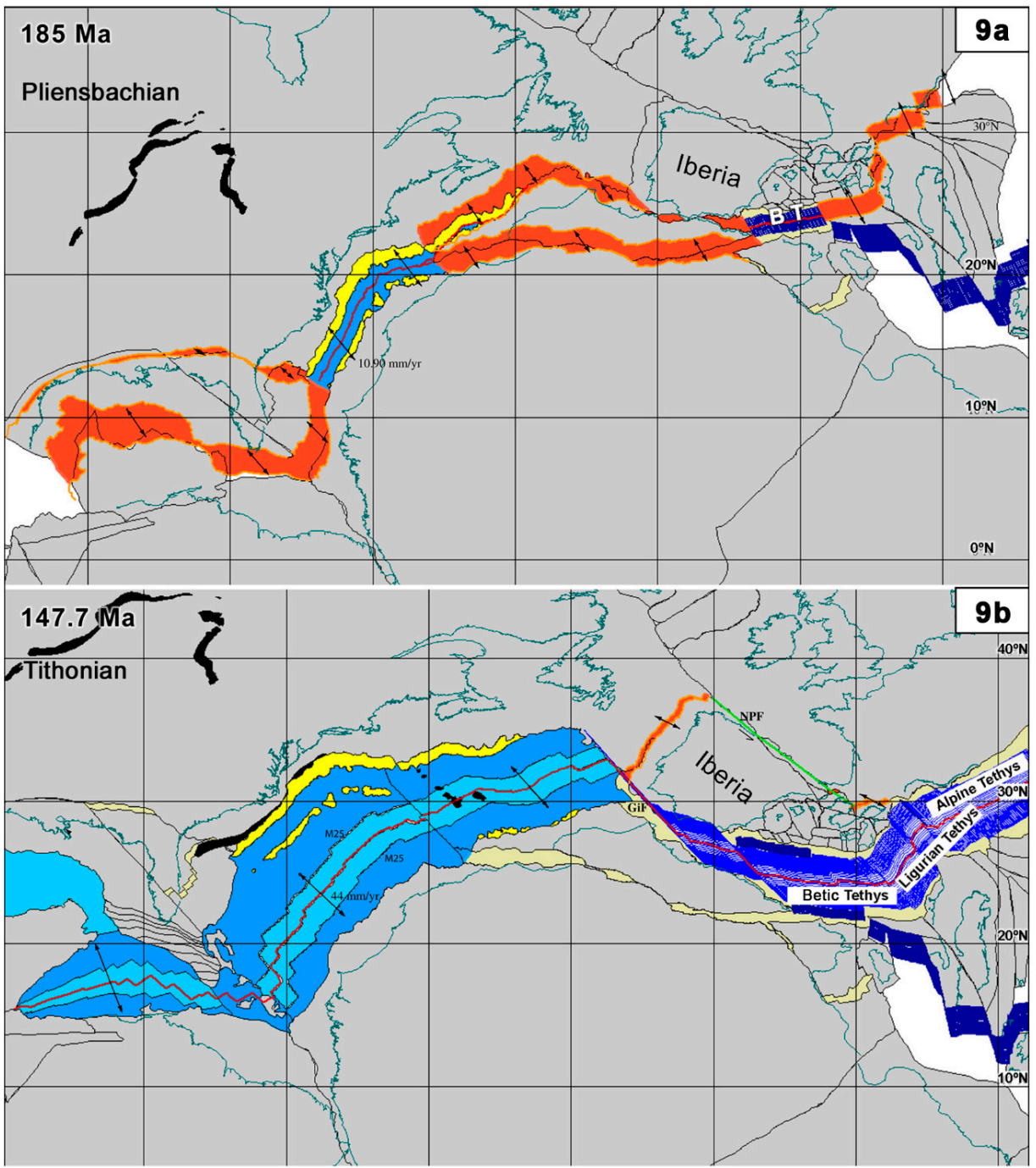

Figure 9. Paleogeographic reconstruction of the Western Tethys and Central Atlantic from Schettino and Turco [74] at $185 \mathrm{Ma}$ (Pliensbachian) (a). and 147.7 Ma (chron 21, Tithonian) (b). The strips represented in red in this Figure, along some zones of the Atlantic, Ligurian and Alpine future oceans, corresponded during the Pliensbachian to rifting zones, that evolved to continental break-up that preceded oceanic floor formation, from the Tithonian onward. In (a) we have indicated the probable location of the Betic Tethys (BT), on the initial oceanic-floor branch of the Western Tethys (represented in dark blue color), according with the Pliensbachian $\mathrm{U} / \mathrm{Pb}$ zircon ages of the Betic ophiolitic gabbros of Lugros and Almirez outcrops [19] complemented, in this paper, by similar dating from Cóbdar and Algarrobo outcrops. In (b) are represented the synthetic isochrons relative to the Tithonian opening of the Tethys oceans, modified by us to locate, in this paper, the Betic Ocean to the western of the Ligurian and Alpine Tethys. GiF: Gibraltar Fault; NPF: North Pyrennean Fault.

In Figure 9a the red-coloured bands represent the zones of fracture and crustal thinning (rifting) marking the break-up of the Pangaea supercontinent from the Triassic, where the Eurasian and African plates separated in this area. The first ocean floors of the Central Atlantic and Western Tethys, marked here in dark blue, began to develop following these rifting patterns approximately $185 \mathrm{Ma}$ ago in the Pliensbachian (Lower Jurassic). The area marked BT (Betic Tethys) between the tectonic microplates located to the SE of Iberia-European plate during the Mesozoic, would correspond to the ridge where the Betic Ophiolites originated. This hypothesis is firmly supported by $\mathrm{U} / \mathrm{Pb}$ radiometric dating with SHRIMP of the zircons separated from eclogitized gabbros and dolerites of the Betic Ophiolites, 
whose absolute magmatic ages correspond to the Pliensbachian (Puga et al. [15,19]; Figures 6 and 7, and Table 1 of this paper). The oceanic floors continued to develop throughout the Jurassic in both the Central Atlantic and the Western Tethys, as shown by the paleogeographic reconstruction of Figure $9 \mathrm{~b}$ for the Tithonian (Late Jurassic). This stage of the paleogeograhic reconstruction agrees with some radiometric and petrologic evidence suggesting continuation of the spreading period of the Betic Tethys up to the Upper Jurassic or even to the Lower Cretaceous, as suggested by sedimentary evidences such as the development of an overlying sedimentary sequence, with cretaceous fossils relics [39], containing some sills with similar mineralogy and chemical composition to the underlying volcanic ophiolites.

\section{Cretaceous Paleogeographic Reconstruction of the Betic Tethys and Eo-Alpine Metamorphic Evolution}

Figure 10 shows the palaeogeographic reconstruction for the Early Cretaceous of the central-western area of the Mediterranean by Guerrera et al. [8], with slight modifications. In this figure, N-F Ocean indicates the area of oceanic floor where the BOA rocks, described in this paper, could have originated SE of the Iberian-European margin for the original paleogeographic continental domains of the tectonic units within which these ophiolites were intercalated. From West to East we have coloured the bands indicating the location of the following Mesozoic Betic Domains: the Subbetic margin, the VC, and the different original domains corresponding to the continental tectonic units forming part of the Mulhacén Complex: Caldera and Sabinas. These two latter units would correspond to both continental margins of the Betic Ocean, or Nevado-Filábride Ocean. The relative provenance of some Betic ophiolitic outcrops is indicated by the letters A to E, according to their current geographical location and differential petrologic and geochemical peculiarities. These characteristics, which are mainly shown in Figure 5D, suggest a probable origin of Cóbdar (D) and Algarrobo (E) outcrops closer to the western continental margin of the Jurassic Betic Ocean than those of Lugros (A), Almirez (B) and Caniles (C) outcrops. Moreover, eastwards the corresponding domains of the Alpujárride (AC) and Maláguide $(\mathrm{MaC})$ Complexes are represented, as well as the emerged areas of the Mesomediterranean Terrane (MT) in the early Cretaceous. According to this reconstruction, at the start of the Cretaceous, the Betic Ocean could have connected the Piemontese-Ligurian (Pi-Li) and the Maghrebian (Mag) Oceans with the Central Atlantic Ocean.

The Jurassic extensional tectonic phase, which originated the opening of the Betic Ocean from the Pliensbachian onward, must have also affected other Betic Domains such as the Alpujárride and the Subbetic, whose relative location during the Mesozoic period is shown in Figure 10. This hypothesis is based on the tectonic setting and ages of the basic magmatism in each of these domains. This extensional tectonic phase affecting the Alpujárride Domain would explain the intrusion of some gabbros and basaltic lenses into the crustal rocks of the Ojen Nappe, identified as eclogites by Tubia et al. [75], which currently host the Ronda peridotites containing pyroxenite dykes. Some zircons from these eclogites and pyroxenites, dated by Sanchez Rodriguez and Gebauer [76], yielded ages from Pliesbachian to early Cretaceous, similar to the basic rocks forming the betic oceanic floor, although their originating magmas, also from asthenospheric origin, were scarcely developed, suggesting aborted rift tectonic conditions, and less effective extension with respect to what occurred in the the Nevado-Filábride domain during the same period. Despite these local tectonic differences, the coincidence of Mesozoic zircon crystallisation ages for two of the main domains of the Betic Cordillera, such as the Nevado-Filábride and the Alpujárride, suggests that in the Betic realm Pangaea actually began to break up in the Pliensbachian ([19] and present paper), and not in the Middle Jurassic as generally reported in the literature (Principi et al. [77]; Bortolotti and Principi [66]; Manatschal and Müntener [28] and references herein). 


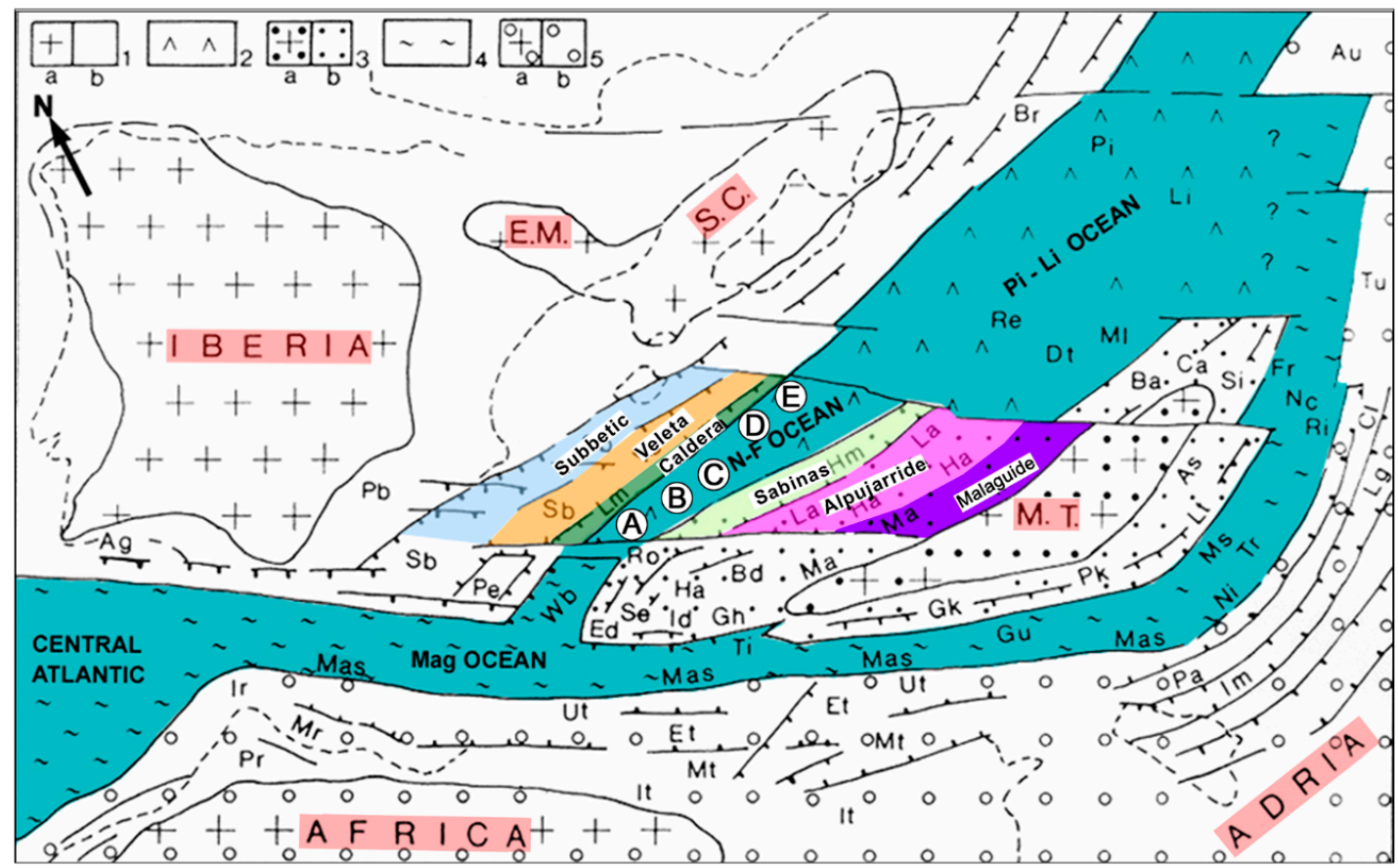

Figure 10. Early Cretaceous paleogeography of the Central-Western Mediterranean region and distribution of the oceanic basins around the Mesomediterranean Terrane (M.T.), mainly the Nevado-Filábride (NF) Ocean, connecting the Piemontese-Liguride (Pi-Li) and the Maghrebian (Mag) oceans with the central Atlantic Ocean (Guerrera et al. [8]). Colored strips represent the different Betic domains, from which the Veleta and Mulhacén complexes derive, which surround the Jurassic-Cretaceous NF Ocean, or Betic Ocean [19]. Letters A, B, C, D and E, indicate the relative provenance of Lugros, Almirez, Caniles, Cóbdar and Algarrobo ophiolitic outcrops along the Betic Ocean, according to their current geographical locations and differential geochemical characteristics. Key for other abbreviations in this figure can be seen in Guerrera et al. [8].

Extensional tectonics during the Jurassic affected also the Subbetic Domain along which a fissural basic magmatism developed, deriving from a lithospheric mantle. This magmatism was dated by K/Ar between the Lower Jurassic up to Lower Cretaceous (Puga [78]; Puga and Portugal Ferrerira [79]; Puga et al. [80-82]; Portugal Ferreira et al. [83]). Some of these ages have been interpreted as partial resetting of the original igneous ages during the alpine metamorphism in prehnite-pumpellyite and pumpellyite-actinolite facies, which was developed mainly in dolerite bodies intruded in Triassic formations, especially for those closer to the Betic Internal Zones, which collided with the External Zones during the Miocene (Morten and Puga [84]; Puga et al. [85,86]; Aguirre et al. [87]).

According to Guerrera et al. ([8] and references herein) the Nevado-Filábride and Ligurian-Piemontese Oceans as well as the northern margin of the Mesomediterranean microplate were structured from Late Cretaceous to the Eocene to create an Eo-Alpine Chain The U-Pb data of zircons from the Betic Ophiolites presented in Puga et al. [15,19] and in Figures 6 and 7, and Table 1 of this paper, showing Upper Cretaceous to Paleocene recrystallization domains on the Jurassic igneous zircon crystals, support the development of this first Alpine tectonic and metamorphic event, which originated the transformation of the basic and ultramafic rocks forming the oceanic-floor, into eclogites, during the Eo-Alpine subduction process as is shown in Figure 11. Eo-Alpine eclogites have been also identified in many other ophiolite outcrops from the Alps, where they have been interpreted as originated by Upper Cretaceous-Paleocene intra-oceanic subduction of the Ligurian sections of the Neothetys, located to the East of Iberian and the west of Adrian microplates (Handy et al. [59] and references herein). 


\section{Neogene Geodynamic Evolution of the Mesomediterranean Terrane}

Subsequently to the Eo-Alpine reestructuration of the Mesomediterranean Terrane, mainly affecting its northern margin, took place, during the late Oligocene and earliest Miocene, the dislaceration of this microplate into the different blocks collectively known, according to Bouillin et al. [88], as AlKaPeCa (Alboran, Kabylian, Peloritan and Calabrian). These blocks were displaced toward the south to attain their respective present locations due to subduction toward the NW and roll-back under them of different oceanic plates, genetically related with the development of the new Mediterranean oceanic basins (Handy et al. [59]; Chalouan and Michard [89]; Lonergan and White [90], Rosebaum et al. [91]; Lustrino et al. [92]). In particular, the Alboran block, or microplate, was displaced to the SW to occupy its present setting between the Iberian and African plates mainly due to the Neogene opening of the Algero-Provençal Basin. During this translation, the different domains of the Alboran microplate, forming the Internal Zones of the Betic and Rifean Cordilleras, collided with their External Zones belonging to the South Iberian and African margins and, together with them, underwent the later alpine stages of deformation and metamorphism. These are characterized by local differences of P-T conditions between the different domains of the Internal Betic Zones, probably due to differential ascent of the asthenosphere below them during the Miocene. These Neogene metamorphic processes, known as Meso-Alpine and Neo-Alpine events, developed in the Nevado-Filábride Domain in Ab-Ep amphibolite and greenschist facies conditions, respectively, overprinting the Eo-Alpine eclogites that were partly retrograded and tectonically deformed.

\section{Genetic and Evolutionary History of the Betic Ophiolites and the Nevado-Filábride Complexes}

Figure 11 shows the origin and evolution of the Betic Ophiolites based on the study of the successive parageneses and textures preserved in them and their thermodynamic formation conditions, together with the radiometric dating of some of their minerals, particularly zircons, and the geochemistry of their different lithologies. Further information is provided by data relative to the tectonic units in which these ophiolites are currently intercalated. This model, based on the previously exposed data in this paper and on other data previously published (Puga et al. [10-19]; Nieto [41]; Nieto et al. [42]; Ruiz Cruz et al. [20,21]; Aerden et al. [23]), shows the schematic geodynamic evolution of the VC and MC from the Carboniferous to the Miocene. It also includes the evolution of the various units comprising the latter complex (MC), one of which is the Ophiolite Unit (Figure 2). Development in time has been divided into several episodes in Figure 11, numbered 1 to 6 , to which correspond successive geological stages affecting both the VC and MC, which are graphically shown and enumerated on the right of the diagram.

The oceanic lithosphere from which the Betic Ophiolites derived was formed in episode 3 by asthenospheric rise, under extensional conditions that persisted throughout the Jurassic and Cretaceous, along a rifting zone on the continental crust of the MC, located between the Caldera (W) and Sabinas (E) units. Among other Pre-Alpine metamorphic rocks, this continental crust contained orthogneisses derived from Hercynian syn-collisional granits (red color) and Permian-Triassic intra-plate rhyolites (blue color) formed earlier in episodes 1,2. In episode 4, the Jurassic-Cretaceous oceanic floor, and part of its continental margins, were subducted toward the SE as a result of a first convergent movement between of the Iberian-European and African-Adria plates beginning in the Late Cretaceous, which caused the Eo-Alpine metamorphism in eclogite facies conditions (Table 1). Genetically related to this subduction episode there are only scarce magmatic products, mainly represented by pyroclastic andesites which, melanged with continental carbonates and gypsum deposits, would gave origin to the Soportújar Formation (SF) ([13] and Figure 2). During episode 5 a small part of the subducted rocks, metamorphosed at depths from 50 up to more than $100 \mathrm{~km}([10,11]$ and Figure 4), were exhumed as tectonic slabs, onto the Caldera domain (its western continental margin), forming the Ophiolite Unit, which was also overthrusted by the Sabinas unit (its eastern continental margin) and by the SF, forming an initial stacking involving the three units of the MC and probably also of the MC onto the VC. During this compressive episode, the Meso-Alpine metamorphic event developed, affecting both 
complexes in Ab-Ep amphibolite facies conditions during the Paleogene (Table 1). Finally, episode 6 took place along the Neogene, during which the Alboran microplate, dismembered from the western part of the Mesomediterranean Terrane, was displaced to the SW, where the metamorphic Internal Zones emplaced on top of the External Zones of the Betic and Rift domains and underwent, together with them, the continental collision between the Iberian and African plates. This collision originatedthe Neo-Alpine metamorphic event, (mainly developed in greenschist facies conditions in the MC and VC), which was followed by the overstacking of the Alpujárride and Maláguide onto the previously empiled Nevado-Filábride Complexes.
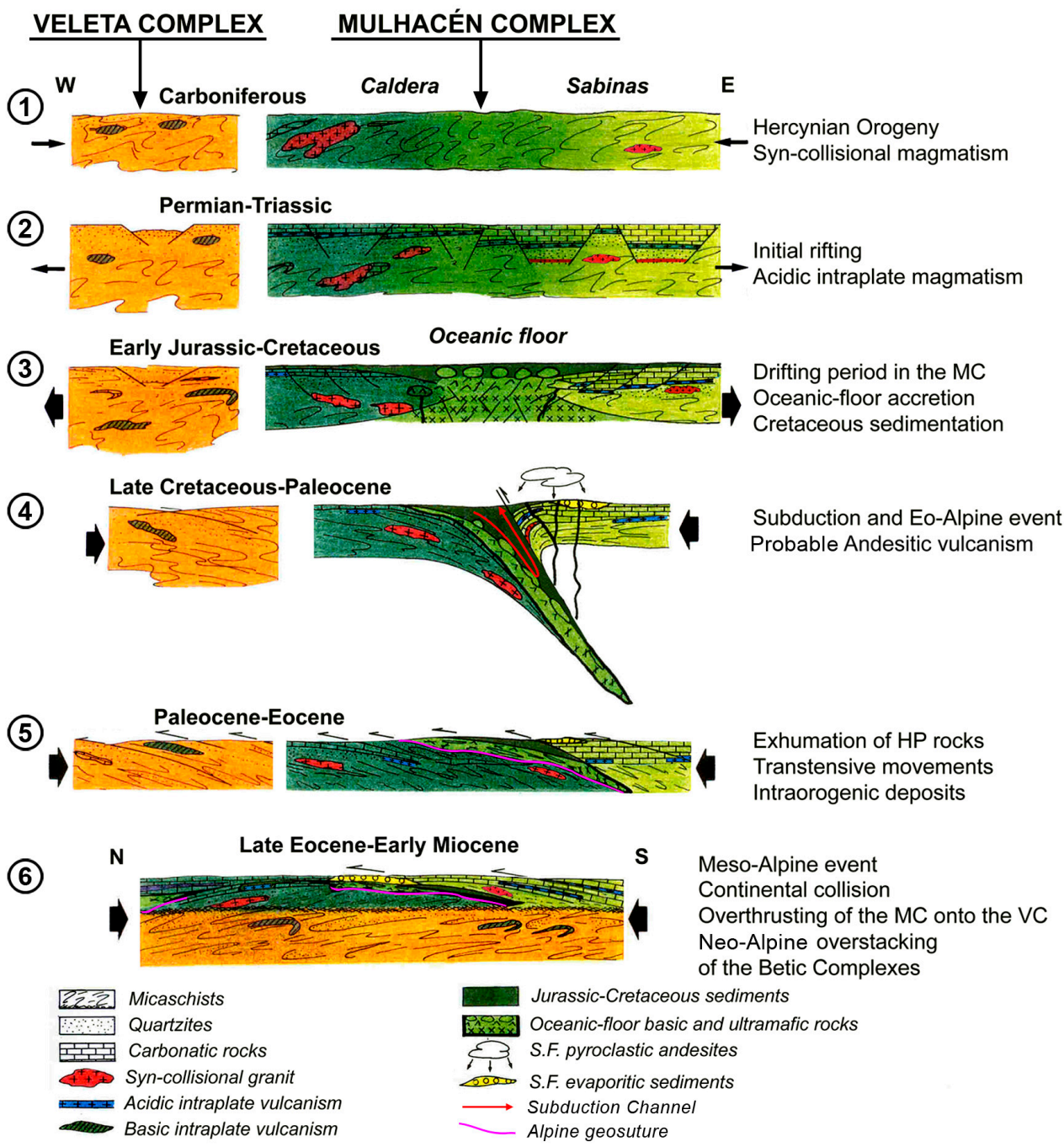

Figure 11. Genetic and evolutionary pattern of the Betic Ophiolites and the continental units of the Nevado-Filábride Complexes, among which they are tectonically intercalated, and Paleogene overthrusting of the Mulhacén Complex onto the Veleta Complex.

\section{Discussion}

The Pangea break-up and subsequent oceanization testified by the Betic Ophiolites occurred between 190 and $180 \mathrm{Ma}$, following Permian and Triassic episodes of rifting and intra-plate volcanism (Puga [1,3,58]; Puga et al. [13,15,19,37,86]; Nieto [41], Nieto et al. [42]; Martin-Martinet al. [93]).

Palinspastic restoration of BOA rocks is not simple and necessarily requires the tentative back-stripping and positioning of the adjoining Alboran domain and continental blocks such as those currently outcropping in crystalline massifs of Kabylie (Algeria) Calabria and Peloritani (Italy) that 
were contiguous to the BOA sections before (and during) the neo-Tethys opening, probably forming a unique microplate known as Mesomediterranean Terrane (Guerrera et al. [8]). This microplate, located to the SE margin of the Iberia-European plate, underwent the effects of the Eo-Alpine Upper Cretaceous Orogeny, by convergence of the Iberia-European and Adria-African plates, with subduction toward the south of the Betic oceanic-floor, followed by Paleocene exhumation of some eclogitized relics on the northern continental margin. This Mesomediterranean microplate was subsequently dismembered into its different continental blocks, collectively known as AlKaPeCa (Alboran, Kabylies, Peloritani, Calabria) [88], from the Oligocene onward due to subduction towards the NW under this terrane of a new oceanic microplate (Guerrera et al. [8]; Handy et al. [59]; Chalouan and Michard [89]; Lonergan and White [90]; Rosebaum et al. [91]; Lustrino et al. [92]; Perez-Lopez and Perez Valera [94]; Critelli et al. [95]).

Consistently with this interpretation, the BOA rocks and those of the surrounded crystalline basements, which formed the continental margins of the Betic Ocean, were involved in the oceanic subduction and the following collision of major continental plates such as Iberia-Europe and Africa, recording similar P-T-t metamorphic paths during the Eo-Alpine orogenic phase that led to the formation of eclogite facies in the MC. This first alpine metamorphic event was followed during the Neogene by the Meso-Alpine and Neo-Alpine orogenic events, which produced the re-crystallisation in the Ab-Ep amphibolite and greenschist facies conditions of the Eo-Alpine eclogites.

The remarkable petrological analogy between the BOA and Alpine-Apennine ophiolites has to be emphasized; it indicates that during the Jurassic they were part of the same oceanic system elongated in a NE-SW direction, that in our view, was westward connected with the embryonic Atlantic Ocean (see Figures 9 and 10). This ocean was unrelated to the oceanic systems represented by the Dinarides and Hellenides ophiolites, which developed eastward and concomitant with active subduction processes. This hypothesis is not based only on ophiolite investigations, but is supported by facies analyses and paleontological studies of coeval sedimentary sequences (Tendero et al. [39]; Lemoine et al. [43]; Lagabrielle et al. [44]; Principi et al. [77]; Perez-Lopez and Perez-Valera [94]; Critelli et al. [95]; Hanne et al. [96]; Martin-Rojas et al. [97]; Somma et al. [98]; Zaghloul et al. [99]).

The described scenario is well represented in the paleogeograhic reconstruction of the Western Tethys of Figure 9, which is perfectly in agreement with the model proposed by Schettino and Turco [74]. According to our radiometric zircon dating on the BOA rocks (Table 1), the Betic oceanic floor initiated its development in the Pliensbachian (from about 190 to $180 \mathrm{Ma}$ ), and continued its metasomatic and metamorphic transformations, under oceanic floor conditions, affecting most of the constituent lithologies, from the ultramafic sequence up to the volcanic one, from the Toarcian to the Tithonian (about 177 to $152 \mathrm{Ma}$ for different outcrops). This was followed by a late magmatic activity originating basaltic sills and dykes having chemical affinity with that of the previous MORB magmas forming the oceanic volcanic and plutonic underlying sequences. These sills are interlayered in the overlying sedimentary sequence, which could be Cretaceous in age (Tendero et al. [39] and references herein) and the scarce dykes cut across some pillowed volcanic layers and more rarely the overlying metasediments. The radiometric dating presented in Table 1, together with the paleogeographic reconstruction of Schettino and Turco [74] for the westernmost segment of the Neotethys (Figure 9), suggest the development of the Betic Ocean for a period of at least 40-50 Ma. On the other hand, the eastward extension of the Betic Tethys Ocean along the Ligurian and Alpine Tethys, that took place from the Middle Jurassic onward, beginning at about $165 \mathrm{Ma}$, developed up to the Upper Tithonian for about 20-30 Ma, according to SHRIMP dating of zircons in the Western and Ligurian Alps and the radiolarians dating of the sedimentary sequence from Tuscan Apennines (see Figures 8 and 9).

The Betic Ocean and its prolongation in the Piemonte-Ligurian domain evolved in slow spreading mode and they were dissected by many transform zones that displaced the ridges settings, leaving significant continental blocks isolated from the adjoining macro-plates.

Major plates re-organization caused cessation of oceanic spreading and incipient consumption of the Neo-Tethys since the Late Cretaceous. As observed in the Alps-Apennine systems, and 
also in the Betic realm, the subduction process developed during several stages characterized by changes in polarity (Lonergan and White [90]; Martin-Martin et al. [93]; Carminati et al. [100]; Verges and Fernandez [101]). The Eo-Alpine subduction, active during Late Cretaceous-Paleocene, was dipping southeastward and plausibly continued up to the continental collision between the south Iberian-European margin and the Mesomediterranean microplate, ultimately leading to obduction of some BOA eclogitized sequences on the western continental margin of the Betic Ocean, formed by the present Caldera Unit of the MC. Then, plate convergence reactivated during Eocene with a reversed polarity characterized by active subduction with remarkable slab passive sinking and roll-back, which allowed extension on the Betic margin originating exhumation of deep mantle rocks and favouring, from Oligocene to Late Miocene, the development of tholeiitic dykes, was followed by extensive calcalkaline and ultrapotassic magmatism (Carminati et al. [100]; Verges and Fernandez [101]; Torres-Roldan et al. [102]; Doblas et al. [103]). The concomitant back arc extension occurring in this Neogene tectonomagmatic phase dismembered the Mesomediterranean microplate, whose remnants progressively migrated to their current settings (Alboran, Kabilies, Peloritani massif and Calabria), mainly due to the opening of the oceanic Algerian-Provençal basin and Tyrrhenian Sea.

\section{Conclusions}

The BOA and the related lithologies, mainly acidic gneissic levels in different units of the MC, dated from 278 to $215 \mathrm{Ma}([13,37,41,42])$ testify that the Pangea continent was affected by pervasive rifting accompanied by acidic volcanism since the Permian/Triassic, which preceded the continental breakup and development of the Jurassic oceanic basin. Rifting and oceanic drifting was plausibly influenced by pre-existing tectonic structures inherited by the Varisic orogeny (Manatschal et al. [104]; Gilard et al. [105]), giving rise to a very complex paleogeography with many ridge offset and short zigzags accommodating seafloor accretion as observed in modern oceanic sectors characterized by slow spreading (Grindlay et al. [106]; Lazar et al. [107]; Kamesh Raju et al. [108]; Murton and Rona, [109]; Mercier de Lèpinay et al. [110]).

In this framework, sharing similar features, the Betic ocean was connected eastward with other oceanic strands currently representing the Liguride ophiolites in the Alpine and Apennine domains, and westward with the embryonic Atlantic Ocean.

According to most recent interpretations, this oceanic corridor having limited width (few hundreds of kilometers) and dissected by many transform zones, was punctuated by Oceanic Core Complexes (OCC) that are dome shaped, with corrugated features, developed along detachment faults (Lagabrielle et al. [31]; Lagabrielle [33]; Manatschal et al. [111]; Li et al. [112]), alternating magmatic sectors characterized by the outcrop of pillow basalts, and amagmatic sectors characterized by the exposure on the seafloor of ultramafic rocks, sometimes intruded by gabbros or dolerite dykes. These associations rarely fit the "Penrose three layer" model constituted by the regular coexistence of ultramafic rocks, basic magmatic rocks and sediments, showing a particular paucity of sheeted dyke complexes. On the contrary, Ligurian Ophiolites are often associated with remnants of the continental crust, and analogously the Betic Ophiolites locally present some indices of crustal assimilation, probably deriving from basement rocks of their continental margin, indicating in both cases (1) vicinity of the continental margin at least during the first stages of the oceanic-floor magmatism, and (2) intermittent spreading generally attributed to ultra-slow spreading ridges [19] or to OCT setting [30].

These tectonomagmatic features, favouring the persistence of isolated continental blocks within the oceanic domain, can explain the close association of the BOA and Ligurian oceanic rocks with continental counterparts, most of which were agglomerated within the microplate known as Mesomediterranean Terrane from which, after the Eo-Alpine orogeny, the AlKaPeCa blocks derived.

The Triassic-Jurassic paleogeography delineated above, obviously influenced the following convergence processes that initiated since the Late Cretaceous following major plate reorganization driven by opening of the South Atlantic basin and anticlockwise rotation of the African plate. The subduction during the Eo-Alpine cycle was dipping to the SE and S direction in the Betic and Alpine 
sectors, respectively. These subduction processes became progressively blocked in ca. $20 \mathrm{Ma}$, probably in relation to continental collision between the above mentioned major plates (Iberia, Europe, Africa) and the interposed Mesomediterranean and Adria microplates, leading to obducion of the Betic and Liguride ophiolite belts. As indicated by the regional distribution of subduction-related volcanism (Wilson and Bianchini [113]; Beccaluva et al. [114-116]; Bianchini et al. [117]) and by geophysical studies (Lucente et al. [118]; Vignaroli et al. [119]; Mancilla et al. [120]) that provide a snapshot of the current geodynamic configuration, further complexity of the Betic and Alpine-Apennine orogenic systems was subsequently induced by Cenozoic subduction processes that were characterized by a flip of polarity, with active subduction dipping toward the N-NW in the Apennine sector, Northward in Maghrebian sector and NE in the circum-Alboran realm.

Acknowledgments: This research was funded by Project CGL2009-12369 of the Spanish Ministry of Science and Innovation, co-financed with FEDER funds, and by Research Group RNM 333 of Junta de Andalucía (Spain). The authors strongly appreciate the detailed revisions of two anonymous reviewers and the Guest Editor of this Ophiolite Volume, so as the discussion, exchange of ideas and revision of previous versions of this manuscript by A. Martín-Algarra and A. García-Casco.

Author Contributions: E. Puga, A. Díaz de Federico, C.M. Fanning and J.M. Nieto conceived and designed the work; C.M. Fanning performed the U/Pb radiometric dating; A. Díaz de Federico, J.A. Rodríguez Martinez-Conde, M.A. Díaz Puga and J.A. Lozano did the field work and sampling; E. Puga, G. Bianchini, C. Natali and L. Beccaluva analyzed the data and wrote the paper.

Conflicts of Interest: The authors declare no conflict of interest.

\section{References}

1. Puga, E. Sur l'existence dans le complexe de la Sierra Nevada (Cordillère Bétique, Espagne du sud) d'éclogites et sur leur origine probable à partir d'une croûte océanique mésozoique. C. R. Acad. Sci. 1977, 285, 1379-1382. (In French)

2. Puga, E.; Díaz de Federico, A. Metamorfismo polifásico y deformaciones alpinas en el Complejo de Sierra Nevada (Cordillera Bética). Implicaciones geodinámicas. In Reunión sobre la Geodinámica de las Cordilleras Béticas y el Mar de Alborán; Universidad de Granada, Secretariado de Publicaciones: Granada, Spain, 1978; pp. 79-111. (In Spanish)

3. Puga, E. The BeticOphiolitic Association (Southeastern Spain). Ofioliti 1990, 15-1, 97-117.

4. Bodinier, J.L.; Morten, L.; Puga, E.; Diaz de Federico, A. Geochemistry of metabasites from the Nevado-Filábride complex, Betic Cordilleras, Spain: Relics of a dismembered ophiolitic sequence. Lithos 1987, 20, 235-245. [CrossRef]

5. Morten, L.; Bargossi, G.M.; Martinez Martinez, J.M.; Puga, E.; Diaz de Federico, A. Metagabbro and associated eclogites in the Lubrín area, Nevado-Filábride Complex, Spain. J. Metamorph. Geol. 1987, 5, 155-174. [CrossRef]

6. Puga, E.; Díaz de Federico, A.; Fediukova, E.; Bondi, M.; Morten, L. The petrology, geochemistry and metamorphic evolution of the ophiolitic eclogites and related rocks from the Sierra Nevada (Betic Cordilleras, Southeastern Spain). Schweizerische Mineralogische und Petrographische Mitteilungen 1989, 69, 435-455.

7. Puga, E.; Díaz de Federico, A.; Bargossi, G.M.; Morten, L. The Nevado-Filábride metaophiolitic association in the Cóbdar region (Betic Cordillera, SE Spain): Preservation of pillow structures and development of coronitic eclogites. Geodin. Acta 1989, 3, 17-36. [CrossRef]

8. Guerrera, F.; Martin-Algarra, A.; Perrone, V. Late Oligocene-Miocene syn-/-late-orogenic successions in Western and Central Mediterranean Chains from the Betic Cordillera to the Southern Apennines. Terra Nova 1993, 5, 525-544. [CrossRef]

9. Puga, E.; Díaz De Federico, A.; Demant, A. The eclogitized pillows of the Betic Ophiolitic Association: Relics of the Tethys ocean floor incorporated to the Alpine Chain after subduction. Terra Nova 1995, 7, 32-43. [CrossRef]

10. Puga, E.; Nieto, J.M.; Díaz De Federico, A.; Bodinier, J.L.; Morten, L. Petrology and metamorphic evolution of ultramafic rocks and dolerite dykes of the BeticOphiolitic Association (Mulhacén Complex, SE Spain): Evidence of eo-Alpine subduction following an ocean-floor metasomatic process. Lithos 1999, 49, 107-140. [CrossRef] 
11. Puga, E.; Nieto, J.M.; Díaz de Federico, A. Contrasting P-T paths in eclogites of the Betic Ophiolitic Association (Mulhacén Complex, SE Spain). Can. Mineral. 2000, 38, 1137-1161. [CrossRef]

12. Gómez-Pugnaire, M.T.; Ulmer, P.; López-Sánchez-Vizcaíno, V. Petrogenesis of the mafic igneous rocks of the Betic Cordilleras: A field, petrological and geochemical study. Contrib. Mineral. Petrol. 2000, 139, 436-457. [CrossRef]

13. Puga, E.; Díaz de Federico, A.; Nieto, J.M. Tectono-stratigraphic subdivison and petrological characterisation of the deepest complexes of the Betic Zone: A Review. Geodin. Acta 2002, 15, 23-43. [CrossRef]

14. Puga, E.; Ruiz Cruz, M.D.; Díaz de Federico, A. Polymetamorphic amphibole veins in metabasalts from the Betic Ophiolitic Association (SE Spain): Relics of ocean-floor metamorphism preserved throughout the Alpine Orogeny. Can. Mineral. 2002, 40, 67-83. [CrossRef]

15. Puga, E.; Fanning, C.M.; Nieto, J.M.; Díaz de Federico, A. New recrystallisation textures in zircons generated by ocean-floor and eclogitefacies metamorphism: A cathodoluminescence and U-Pb SHRIMP study with constraints from REE elements. Can. Mineral. 2005, 42, 1349-1368.

16. Puga, E.; Díaz de Federico, A.; Nieto, J.M.; Díaz Puga, M.A. Petrología, georrecursos y evolución geodinámica del Espacio Natural de Sierra Nevada. Estud. Geol. 2007, 63/2, 19-40. (In Spanish)

17. Puga, E.; Díaz de Federico, A.; Nieto, J.M.; Díaz Puga, M.A. The Betic Ophiolitic Association: A very significant geological heritage in urgent need of preservation. Geoheritage 2009, 1, 11-31. [CrossRef]

18. Puga, E.; Rodríguez Martínez-Conde, J.A.; Díaz de Federico, A.; Manteca Martínez, J.I.; Díaz Puga, M.A. Caracterización geoquímica y ambiente geodinámico de génesis de las metabasitas de la Sierra del Algarrobo (Cordillera Bética oriental). Geogaceta 2009, 46, 11-14. (In Spanish)

19. Puga, E.; Fanning, M.; Díaz de Federico, A.; Nieto, J.M.; Beccaluva, L.; Bianchini, G.; Díaz Puga, M.A. Petrology, geochemistry and U-Pb geochronology of the Betic Ophiolites: Inferences for Pangaea break-up and birth of the westernmost Tethys Ocean. Lithos 2011, 124, 255-272. [CrossRef]

20. Ruiz Cruz, M.D.; Puga, E.; Nieto, J.M. Silicate and ore exsolutions in pseudo-spinifex olivine of the metaultramafic rocks from the Betic Ophiolitic Association: A TEM study. Am. Mineral. 1999, 11-12, 1915-1924. [CrossRef]

21. Ruiz Cruz, M.D.; Puga, E.; Díaz de Federico, A. Exsolution microstructures in amphiboles from metabasalts of the Betic ophiolitic association (SE Spain). Eur. J. Mineral. 2007, 19, 547-556. [CrossRef]

22. Alt, J.C.; Garrido, C.J.; Shanks III, W.C.; Turchyn, A.; Padrón-Navarta, J.A.; López Sánchez-Vizcaíno, V.; Gómez-Pugnaire, M.T.; Marchesi, C. Recycling of water, carbon and sulfur during subduction of serpentinites: A stable isotope study of Cerro del Almirez, Spain. Earth Planet. Sci. Lett. 2012, 327-328, 50-60. [CrossRef]

23. Aerden, D.G.A.M.; Bell, T.H.; Puga, E.; Sayab, M.; Lozano, J.A.; Díaz de Federico, A. Multi-stage mountain building vs. relative plate motions in the Betic Cordillera deduced from integrated microstructural and petrological analysis of porphyroblast inclusion trails. Tectonophysics 2013, 587, 188-206. [CrossRef]

24. Beccaluva, L.; Macciotta, G.; Piccardo, G.B.; Zeda, O. Petrology of lherzolitic rocks from the Northern Apennine ophiolites. Lithos 1984, 17, 299-316. [CrossRef]

25. Beccaluva, L.; Coltorti, M.; Saccani, E.; Siena, F.; Zeda, O. Triassic magmatism and Jurassic Ophiolites at the margins of the Adria Plate. In Crop Project-Deep Seismic Exploration of the Central Mediterranean and Italy; Finetti, I., Ed.; Elsevier Science: Amsterdam, The Netherlands, 2005; pp. 607-621.

26. Marroni, M.; Molli, G.; Montanini, A.; Tribuzio, R. The association of continental crust rocks with ophiolites in the Northern Apennines (Italy): Implications for the continent-ocean transition in the Western Tethys. Tectonophysics 1998, 292, 43-66. [CrossRef]

27. Montanini, A.; Tribuzio, R.; Vernia, L. Petrogenesis of basalts and gabbros from an ancient continent-ocean transition (External Liguride ophiolites, Northern Italy). Lithos 2008, 101, 453-479. [CrossRef]

28. Manatschal, G.; Müntener, O. A type sequence across an ancient magma-poor ocean-continent transition: The example of the western Alpine Tethys ophiolites. Tectonophysics 2009, 473, 4-19. [CrossRef]

29. Piccardo, G.B.; Guarnieri, L. Alpine peridotites from the Ligurian Tethys: An updated critical review. Int. Geol. Rev. 2010, 52, 1138-1159. [CrossRef]

30. Saccani, E.; Dilek, Y.; Marroni, M.; Pandolfi, L. Continental margin ophiolites of Neotethys: Remnants of Ancient Ocean-Continent Transition Zone (OCTZ) lithosphere and their geochemistry, mantle sources and melt evolution patterns. Episodes 2015, 38, 230-249.

31. Lagabrielle, Y.; Brovarone, A.V.; Ildefonse, B. Fossil oceanic core complexes recognized in the blueshist metaophiolites of western Alps and Corsica. Earth Sci. Rev. 2015, 141, 1-26. [CrossRef] 
32. Dick, H.J.B.; Lin, J.; Schouten, H. An ultraslow-spreading class of ocean ridge. Nature 2003, 426, 405-412. [CrossRef] [PubMed]

33. Lagabrielle, Y. Mantle exhumation and lithospheric spreading: An historical perspective from investigations in the Oceans and in the Alps-Apennines ophiolites. Ital. J. Geosci. (Boll. Soc. Geol. Ital.) 2009, 128, $279-293$.

34. Gale, A.; Laubier, M.; Escrig, S.; Langmuir, C.H. Constraints on melting processes and plume-ridge interaction from comprehensive study of the FAMOUS and North Famous segments, Mid-Atlantic Ridge. Earth Planet. Sci. Lett. 2013, 365, 209-220. [CrossRef]

35. Herbrich, A.; Hauff, F.; Hoernle, K.; Werner, R.; Garbe-Schönberg, D.; White, S. A 1.5 Ma record of plume-ridge interaction at the Western Galápagos Spreading Center $\left(91^{\circ} 40^{\prime}-92^{\circ} 00^{\prime} \mathrm{W}\right)$. Geochimica et Cosmochimica Acta 2015, 185, 141-159. [CrossRef]

36. Regelous, M.; Weinzierl, C.G.; Haase, K.M. Controls on melting at spreading ridges from correlated abyssal peridotite - mid-ocean ridge basalt compositions. Earth Planet. Sci. Lett. 2016, 449, 1-11. [CrossRef]

37. Puga, E.; Díaz de Federico, A.; Nieto, J.M.; Díaz Puga, M.A.; Rodríguez Martínez Conde, J.A.; Manteca Martínez, J.I. Argumentos petrológicos y geoquímicas para la subdivisión del Complejo Nevado-Filábride en los Complejos del Veleta y del Mulhacén. VI Congreso Geológico de España, Zaragoza (España). Geo-Temas 2004, 6, 101-104. (In Spanish)

38. Puga, E.; Díaz de Federico, A.; Manteca Martínez, J.I.; Rodríguez Martínez Conde, J.A.; Díaz Puga, M.A. The Canteras-Galifa Neogene conglomerates: Evidence for an ophiolitic association submerged in the Mediterranean Sea at the Eastern end of the Betic Chain. Ofioliti 2004, 29, 213-230.

39. Tendero, J.A.; Martin-Algarra, A.; Puga, E.; Díaz De Federico, A. Lithostratigraphie des métasédiments de l'association ophiolitique Nevado-Filábride (SE Espagne) et mise en evidence d'objets ankéritiques évoquant des foraminiféres planctoniques du Crétacé: Conséquences paléogéographiques. C. R. Acad. Sci. 1993, 316, 1115-1122. (In French)

40. Puga, E.; Ruiz Cruz, M.D.; Díaz De Federico, A. Magnetite-silicate inclusions in olivine of ophiolitic meta-gabbros from the Mulhacén Complex (Betic Cordillera, SE Spain). Can. Mineral. 1999, 37, 1191-1209.

41. Nieto, J.M. Petrología y Geoquímica de los Ortogneises del Complejo del Mulhacén, Cordilleras Béticas. Ph.D. Thesis, Universidad de Granada, Granada, Spain, 1996; p. 211.

42. Nieto, J.M.; Puga, E.; Díaz de Federico, A. Late Variscan pyroclastic rocks from the Mulhacén Complex (Betic Cordillera, Spain), 217-24. In Volcaniclastic Rocks, from Magmas to Sediments; Leyrit, H., Montenat, C., Eds.; Gordon and Breach Science Publishers: Philadelphia, PA, USA, 2000; p. 265.

43. Lemoine, M.; Marthaler, M.; Carón, M.; Sartori, M.; Amaudric Du Chaffaut, S.; Dumont, T.; Escher, A.; Masson, H.; Polino, R.; Tricart, P. Découverte de foraminiféres planctoniques du Crétacé supérieur dans les schistes lustres du Queyras (Alpes occidentales), Conséquences paléogéographiques et tectoniques. C. R. Acad. Sci. 1984, 299, 727-732. (In French)

44. Lagabrielle, Y.; Polino, R.; Auzende, J.M.; Blanchet, R.; Caby, R.; Fudral, S.; Lemoine, M.; Mevel, C.; Ohnenstetter, M.; Robert, D.; et al. Les témoins d'une tectonique intraocéanique dans le domaine téthysien: Analyse des rapports entre les ophiolites et leurs couvertures métasédimentaires dans la Zone Piémontaise des Alpes franco-italiennes. Ofioliti 1984, 9, 67-88. (In French)

45. Shervais, J.W. Ti-V plots and the petrogenesis of modern ophiolitic lavas. Earth Planet. Sci. Lett. 1982, 59, 101-118. [CrossRef]

46. Pearce, J.A. Trace element characteristics of lavas from destructive plate boundaries. In Andesites; Thorpe, R.S., Ed.; John Wiley \& Sons: Hoboken NJ, USA; pp. 525-548.

47. Boynton, W.V. Cosmochemistry of the rare earth elements: Meteorite studies. In Rare Earth Element; Henderson, P., Ed.; Geochemistry Elsevier: Amsterdam, The Netherlands, 1984; pp. 63-114.

48. Snow, J.E.; Hart, S.R.; Dick, H.J.B. Nd and Sr isotope evidence linking mid-oceanridge basalts and abyssal peridotites. Nature 1994, 371, 57-60. [CrossRef]

49. Hoffman, A.V. Mantle geochemistry: The message from oceanic volcanism. Nature 1997, 385, $219-229$. [CrossRef]

50. Marzoli, A.; Renne, P.R.; Piccirillo, E.M.; Ernesto, M.; Bellieni, G.; De Min, A. Extensive 200-Million-year-old continental flood basalts of the Central Atlantic Magmatic Province. Science 1999, 284, 616-618. [CrossRef] [PubMed] 
51. Saccani, E.; Photiades, A.; Beccaluva, L. Petrogenesis and tectonic significance of Jurassic IAT magma types in the Hellenide ophiolites as deduced from the Rhodiani ophiolites (Pelagonian zone, Greece). Lithos 2008, 104, 71-84. [CrossRef]

52. Saccani, E.; Beccaluva, L.; Photiades, A.; Zeda, O. Petrogenesis and tectono-magmatic significance of basalts and mantle peridotites from the Albanian-Greek ophiolites and sub-ophiolitic mélanges. New constraints for the Triassic-Jurassic evolution of the Neo-Tethys in the Dinaride sector. Lithos 2011, 124, 227-242. [CrossRef]

53. Sun, S.S.; McDonough, W.F. Chemical and isotopic systematic of oceanic basalts; implications for mantle composition and processes. In Magmatism in the Oceanic Basins (Special Publication Geological Society of London); Saunders, A.D., Norry, M.J., Eds.; Geological Society: London, UK, 1989; Volume 42, pp. 313-345.

54. Pearce, J.A. Inmobile element fingerprinting of Ophiolites. Elements 2014, 10, 101-108. [CrossRef]

55. Piccardo, G.B. The Jurassic Ligurian Tethys, a fossil ultraslow-spreading ocean: The mantle perspective. Geol. Soc. Lond. Spec. Publ. 2008, 293, 11-34. [CrossRef]

56. Michael, P.J.; Langmuir, C.H.; Dick, H.J.B.; Snow, J.E. Magmatic and amagmatic seafloor generation at the ultraslow-spreading Gakkel ridge, Arctic Ocean. Nature 2003, 423, 956-961. [CrossRef] [PubMed]

57. Jones, C.E.; Jenkyns, H.C.; Coe, A.L.; Hesselbo, S.P. Strontium isotopic variations in Jurassic and Cretaceous seawater. Geochim. Cosmochim. Acta 1994, 58, 3061-3074. [CrossRef]

58. Puga, E. A reappraisal of the Betic Ophiolitic Association: The westernmost relic of the Alpine Tethys Ocean). In Deep Seismic Exploration of the Central Mediterranean and Italy; Finetti, I.R., Ed.; CROP 1 Volume; Elsevier: Amsterdam, The Netherlands, 2005; pp. 665-704.

59. Handy, M.R.; Schmid, S.M.; Bousquet, R.; Kissling, E.; Bernoulli, D. Reconciling plate-tectonic reconstructions of Alpine Tethys with the geological-geophysical record of spreading and subduction in the Alps. Earth Sci. Rev. 2010, 102, 121-158. [CrossRef]

60. Puga, E.; Díaz de Federico, A.; Bodinier, J.L.; Monié, P.; Morten, L. The Betic Ophiolitic eclogites (Nevado-Filábride Complex, SE Spain). In Proceedings of the Terra Nova Abstr Second Eclogite Field Symposium, Granada, Spain, 4-10 September 1991; Supplement 6, pp. 9-10.

61. Portugal Ferreira, M.; Ferreira, J.D.; Puga, E.; Díaz de Federico, A. Geochronological contribution to the petrogenetic picture of the Betic Chain (SE Spain). II Congr. Geol. Esp. Com. 1988, 2, 55-58.

62. Monié, P.; Galindo-Zaldivar, J.; Gonzalez Lodeiro, F.; Goffe, B.; Jabaloy, A. 40Ar/39Ar geochronology of Alpine tectonism in the Betic Cordilleras (southern Spain). J. Geol. Soc. 1991, 148, 289-297. [CrossRef]

63. López Sánchez-Vizcaíno, V.; Rubatto, D.; Gómez Pugnaire, M.T.; Trommsdorff, V.; Müntener, O. Middle Miocene high-pressure metamorphism and fast exhumation of the Nevado-Filábride Complex, SE Spain. Terra Nova 2001, 13, 327-332. [CrossRef]

64. De Jong, K. Very fast exhumation of high-pressure metamorphic rocks with excess $40 \mathrm{Ar}$ and inherited 87Sr, Betic Cordilleras, southern Spain. Lithos 2003, 70, 91-110. [CrossRef]

65. Hebeda, E.H.; Boelrijk, N.A.I.M.; Priem, H.N.A.; Verdurmen, E.A.T.; Verschure, R.H.; Simon, O.J. Excess radiogenic $\mathrm{Ar}$ and undisturbed $\mathrm{Rb}-\mathrm{Sr}$ systems in basic intrusives subjected to Alpine metamorphism in southeastern Spain. Earth Planet. Sci. Lett. 1980, 47, 81-90. [CrossRef]

66. Bortolotti, V.; Principi, G. Tethyan ophiolites and Pangaea breakup. Isl. Arcs 2005, 14, 442-470. [CrossRef]

67. Borsi, L.; Schärer, U.; Gaggero, L.; Crispini, L. Age, origin and geodynamic significance of plagiogranites in lherzolites and gabbros of the Piedmont-Ligurian ocean basin. Earth Planet. Sci. Lett. 1996, 140, 227-241. [CrossRef]

68. Costa, S.; Caby, R. Evolution of the Ligurian Tethys in the Western Alps: Sm/Nd and U/Pb geochronology and rare-earth element geochemistry of the Montgenève ophiolite (France). Chem. Geol. 2001, 175, 449-466. [CrossRef]

69. Rubatto, D.; Scambelluri, M. U-Pb dating of magmatic zircon and metamorphic baddeleyite in the Ligurian eclogites (Voltri Massif, Western Alps). Contrib. Mineral. Petrol. 2003, 146, 341-355. [CrossRef]

70. Kaczmarek, M.A.; Müntener, O.; Rubatto, D. Trace element chemistry and U-Pb dating of zircons oceanic gabbros and their relationship with whole rock composition (Lanzo, Italian Alps). Contrib. Mineral. Petrol. 2008, 155, 295-312. [CrossRef]

71. Bill, M.; Bussy, F.; Cosca, M.; Masson, H.; Hunziker, J. High-precision U-Pb and 40Ar/39Ar dating of an Alpine ophiolite (Gets nappe, French Alps. Eclogae Geol. Helv. 1997, 90, 43-54.

72. Tribuzio, R.; Thirlwall, M.F.; Vannucci, R. Origin of the Gabbro-Peridotite Association from the Northern Apennine Ophiolites (Italy). J. Petrol. 2004, 45, 1109-1124. [CrossRef] 
73. Rampone, E.; Borghini, G.; Romairone, A.; Abouchami, W.; Class, C.; Goldstein, S.L. Sm-Nd geochronology of the Erro-Tobbio gabbros (Ligurian Alps, Italy): Insights into the evolution of the Alpine Tethys. Lithos 2014, 205, 236-246. [CrossRef]

74. Schettino, A.; Turco, E. Breakup of Pangaea and Plate Kinematics of the central Atlantic and Atlas region. Geophys. J. Inter. 2009, 178, 1078-1097. [CrossRef]

75. Tubía, J.M.; Cuevas, J.; Esteban, J.J.; Ibarguchi, G. Remnants of a Mesozoic rift in subducted terrane of the Alpujarrride Complex (Betic Cordilleras, Southern Spain). J. Geol. 2009, 117, 71-87. [CrossRef]

76. Sánchez-Rodríguez, L.; Gebauer, D. Mesozoic formation of pyroxenites and gabbros in the Ronda area (southern Spain), followed by Early Miocene subduction metamorphism and emplacement into the middle crust: $\mathrm{U}-\mathrm{Pb}$ sensitive high resolution ion microprobe dating of zircon. Tectonophysics 2000, 316, $19-44$. [CrossRef]

77. Principi, G.; Bortolotti, V.; Chiari, M.; Cortesogno, L.; Gaggero, L.; Marcucci, M.; Saccani, E.; Treves, B. The pre-orogenic volcano-sedimentary covers of the Western Tethys oceanic basin: A review. Ofioliti 2004, 29, 177-211.

78. Puga, E. Enclaves de micaschistes à silicates d'alumine dans les roches volcaniques basiques mèsozoiques de la Cordillère Subbètique: Premiers tèmoins d'un socle, non affleurant, dans les Zones Betiques Externes (Spagne du Sud). C. R. Acad. Sci. 1987, 305, 1503-1506. (In French)

79. Puga, E.; Portugal Ferreira, M. The recrystallization and partial melting of xenoliths of pelitic rocks and their bearing on the contaminated basalts (Subbetic Zone, Spain). In Magma-Crust Interactions and Evolution; Bonin, B., Didier, J., Le Fort, P., Propach, G., Puga, E., Vistelius, A.B., Eds.; Theophrastus Publications: Athens, Greece, 1989; pp. 115-159.

80. Puga, E.; Portugal, M.; Díaz De Federico, A.; Bargossi, G.M.; Morten, L. The evolution of the magmatism in the external zones of the Betic Cordilleras during the Mesozoic. Geodin. Acta 1989, 3, 253-266. [CrossRef]

81. Puga, E.; Van de Fliert, J.R.; Torres Roldan, R.L.; Sanz de Galdeano, C. Attempts of whole-rock K/Ar dating of Mesozoic volcanic and hypabissal igneous rocks from the Central Subbetic (Southern Spain): A case of differential Argon loss related to very low-grade metamorphism. Estud. Geol. 1988, 44, 47-59. [CrossRef]

82. Puga, E.; Morata, D.; Díaz de Federico, A. Magmatísmo Mesozoico y metamorfismo de muy bajo grado de las Zonas Externas Béticas. In Geología de España; Vera, J.A., Ed.; Sociedad Geográfica de España, Instituto Geológico y Minero de España: Madrid, Spain, 2004; pp. 386-387. (In Spanish)

83. Portugal-Ferreira, M.; Morata, D.; Puga, E.; Demant, A.; Aguirre, L. Evolución geoquímica y temporal del magmatismo básico Mesozoico en las Zonas Externas de las Cordilleras Béticas. Estud. Geol. 1995, 51, 109-118. (In Spanish) [CrossRef]

84. Morten, L.; Puga, E. Augite to chloromelanite transformation in ophites from the Subbetic Zone, Betic Cordilleras, Spain. Periodico di Mineralogia 1983, 52, 355-367.

85. Puga, E.; Morten, L.; Bondi, M.; Bargossi, J.M.; Ruiz Cruz, M.D.; Diaz de Federico, A. Metamorphosed “Ophites" from Archidona Region, Subbetic Zone (Spain). Estud. Geol. 1983, 39, 307-317.

86. Puga, E.; Beccaluva, L.; Bianchini, G.; Díaz De Federico, A.; Díaz Puga, M.A.; Alvarez-Valero, A.; Galindo-Zaldívar, J.; Wijbrans, J.R. First evidence of lamprophyric magmatism within the Subbetic Zone (Southern Spain). Geol. Acta 2010, 8, 111-130.

87. Aguirre, L.; Morata, D.; Puga, E.; Baronet, A.; Beiersdorfer, R.E. Chemistry and crystal characteristics of pumpellyite in a metadolerite from the Archidona region, Subbetic Cordillera, Spain. Geol. Soc. Am. 1995, 296, 171-181.

88. Bouillin, J.P.; Durand-Delgá, M.; Olivier, P. Betic-Rifain and Tyrrenian Arcs: Distinctive features, genesis and development stages. In The Origin of Arcs; Wezel, F.C., Ed.; Elsevier: Amsterdam, The Netherlands, 1986; pp. 281-304.

89. Chalouan, A.; Michard, A. The Alpine Rif Belt (Morocco): A Case of Mountain Building in a Subduction-Subduction-Transform Fault Triple Junction. Pure Appl. Geophys. 2004, 161, 489-519. [CrossRef]

90. Lonergan, L.; White, N. Origin of the Betic-Rif mountain belt. Tectonics 1997, 16, 504-522. [CrossRef]

91. Rosebaum, G.; Lister, G.S. Reconstruction of the evolution of the Alpine-Himalayan Orogen. J. Virtual Explor. 2002, 8, 107-130.

92. Lustrino, M.; Duggen, S.; Rosenberg, C.L. The Central-Western Mediterranean: Anomalous igneous activity in an anomalous collisional tectonic setting. Earth-Sci. Rev. 2011, 104, 1-40. [CrossRef] 
93. Martín-Martín, M.; Sanz de Galdeano, C.; García-Tortosa, F.C.; Martín-Rojas, I. Tectonic units from the Sierra Espuña-Mula area (SE Spain): Implication on the Triassic paleogeography and the geodynamic evolution for the Betic-Rif Internal Zone. Geodin. Acta 2006, 19, 1-15. [CrossRef]

94. Perez-Lopez, A.; Perez Valera, F. Paleogeography, facies and nomenclature of the Trias units in the different domains of the Betic Cordillera (S Spain). Palaegeogr. Palaeoclimatol. Palaeoecol. 2007, 254, 606-626. [CrossRef]

95. Critelli, S.; Mongelli, G.; Perri, F.; Martin-Algarra, A.; Martin-Martin, M.; Perrone, V.; Dominici, R.; Sonnino, M.; Zaghloul, M.N. Compositional and geochemical signatures for the sedimentary evolution of the Middle Triassic-Lower Jurassic Continental Redbeds from Western-Central Mediterranean Alpine Chains. J. Geol. 2008, 116, 375-386. [CrossRef]

96. Hanne, D.; White, N.; Lonergan, L. Subsidence analyses from the Betic Cordillera, Southeast Spain. Basin Res. 2003, 15, 1-21. [CrossRef]

97. Martin-Rojas, I.; Somma, R.; Delgado, F.; Estévez, A.; Iannace, A.; Perrone, V.; Zamparelli, V. Triassic continental rifting of Pangaea: Direct evidence from the Alpujárride carbonates, Betic Cordillera, SE Spain. J. Geol. Soc. 2009, 166, 447-458. [CrossRef]

98. Somma, R.; Martin-Rojas, I.; Zamparelli, V.; Delgado Salazar, F.; Estévez Rubio, A.; Iannace, A.; Perrone, V. First Record of Tethyan Ladinian involutinid foraminifera-rich beds in the Betic Internal Zone (SE Spain). Geogaceta 2010, 48, 67-70.

99. Zaghloul, M.N.; Critelli, S.; Perri, F.; Mongelli, G.; Perrone, V.; Sonnino, M.; Tucker, M.; Aiello, M.; Ventimiglia, C. Depositional systems, composition and geochemistry of Triassic rifted-continental margin of the Internal Rif Chain, Morocco. Sedimentology 2010, 57, 312-350. [CrossRef]

100. Carminati, E.; Lustrino, M.; Doglioni, C. Geodynamic evolution of the central and western Mediterranean: Tectonics vs. igneous petrology constraints. Tectonophysics 2012, 579, 173-192. [CrossRef]

101. Vergés, J.; Fernàndez, M. Tethys-Atlantic interaction along the Iberia-Africa plate boundary: The Betic-Rif orogenic system. Tectonophysics 2012, 579, 144-172. [CrossRef]

102. Torres-Roldan, R.L.; Poli, G.; Peccerillo, A. An Early Miocene arc-tholeiitic magmatic dike event from the Alboran Sea-Evidence for precollisional subduction and back-arc crustal extension in the westernmost Mediterranean. Geol. Rundsch. 1986, 75/1, 219-234. [CrossRef]

103. Doblas, M.; López-Ruiz, J.; Cebriá, J. Cenozoic evolution of the Alboran Domain: A review of the tectonomagmatic models. Geol. Soc. Am. 2007, 418, 303-320.

104. Manatschal, G.; Lavier, L.; Chenin, P. The role of inheritance in structuring hyperextended rift systems: Some considerations based on observations and numerical modeling. Gondwana Res. 2015, 27, 140-164. [CrossRef]

105. Gillard, M.; Autin, J.; Manatschal, G. Fault systems at hyper-extended rifted margins and embryonic oceanic crust: Structural style, evolution and relation to magma. Mar. Pet. Geol. 2016, 76, 51-67. [CrossRef]

106. Grindlay, N.R.; Madsen, J.A.; Rommevaux-Jestin, C.; Sclater, J. A different pattern of ridge segmentation and mantle Bouguer gravity anomalies along the ultra-slow spreading Southwest Indian Ridge $\left(15^{\circ} 30^{\prime} \mathrm{E}\right.$ to $25^{\circ}$ E). Earth Planet. Sci. Lett. 1998, 161, 243-253. [CrossRef]

107. Lazar, M.; Ben-Avraham, Z.; Garfunkel, Z. The Red Sea-New Insights from recent geophysical studies and the connection to the Dead Sea fault. J. Afr. Earth Sci. 2012, 68, 96-110. [CrossRef]

108. Kamesh Raju, K.A.; Samudrala, K.; Drolia, R.K.; Amarnath, D.; Ramachandran, R.; Mudholkar, A. Segmentation and morphology of the Central Indian Ridge between $3^{\circ} \mathrm{S}$ and $11^{\circ} \mathrm{S}$, Indian Ocean. Tectonophysics 2012, 554-557, 114-126. [CrossRef]

109. Murton, B.J.; Rona, P.A. Carlsberg Ridge and Mid Atlantic Ridge: Comparison of slow spreading centre analogues. Deep Sea Res. Part II 2015, 121, 71-84. [CrossRef]

110. Mercier de Lépinay, M.; Loncke, L.; Basile, C.; Roest, W.R.; Patriat, M.; Maillard, A.; De Clarens, P. Transform continental margins-Part 2: A worldwide review. Tectonophysics 2016, 693, 96-115. [CrossRef]

111. Manatschal, G.; Sauter, D.; Karpoff, A.M.; Masini, E.; Mohn, G.; Lagabrielle, Y. The Chenaillet Ophiolite in the French/Italian Alps: An ancient analogue for an Oceanic Core Complex? Lithos 2015, 124, 169-184. [CrossRef]

112. Li, X.-H.; Faure, M.; Lin, W.; Manatschal, G. New isotopic constraints on age and magma genesis of an embryonic oceanic crust: The Chenaillet Ophiolite in the Western Alps. Lithos 2013, 160-161, 283-291. [CrossRef]

113. Wilson, M.; Bianchini, G. Tertiary-Quaternary magmatism within the Mediterranean and surrounding regions. Geol. Soc. Lond. Spec. Publ. 1999, 156, 141-168. [CrossRef] 
114. Beccaluva, L.; Bianchini, G.; Coltorti, M.; Siena, F.; Verde, M. Cenozoic tectono-magmatic evolution of the central-western mediterranean: Migration of an arc-interarc basin system and variations in the mode of subduction. In Crop Project_-Deep Seismic Exploration of the Central Mediterranean and Italy"; Finetti, I., Ed.; Elsevier Science: Amsterdam, The Netherlands, 2005; pp. 623-640.

115. Beccaluva, L.; Bianchini, G.; Natali, C.; Siena, F. Geodynamic control on orogenic and anorogenic magmatic phases in Sardinia and Southern Spain: Inferences for the Cenozoic evolution of the western Mediterranean. Lithos 2011, 123, 218-224. [CrossRef]

116. Beccaluva, L.; Bianchini, G.; Mameli, P.; Natali, C. Miocene shoshonite volcanism in Sardinia: Implications for magma sources and geodynamic evolution of the central-western Mediterranean. Lithos 2013, 180-181, 128-137. [CrossRef]

117. Bianchini, G.; Beccaluva, L.; Siena, F. Subduction-related and intraplate Cenozoic volcanism in the rifted Apennines/Adriatic domain. Lithos 2008, 101, 125-140. [CrossRef]

118. Lucente, F.P.; Margheriti, L.; Piromallo, C.; Barruol, G. Seismic anisotropy reveals the long route of the slab through the western-central Mediterranean mantle. Earth Planet. Sci. Lett. 2006, 241, 517-529. [CrossRef]

119. Vignaroli, G.; Faccenna, C.; Jolivet, L.; Piromallo, C.; Rossetti, F. Subduction polarity reversal at the junction between the Western Alps and the Northern Apennines, Italy. Tectonophysics 2008, 450, 34-50. [CrossRef]

120. Mancilla, F.D.L.; Booth-Rea, G.; Stich, D.; Pérez-Peña, J.V.; Morales, J.; Miguel Azañón, J.; Martin, R.; Giaconia, F. Slab rupture and delamination under the Betics and Rif constrained from receiver functions. Tectonophysics 2015, 663, 225-237. [CrossRef]

(C) 2017 by the authors. Licensee MDPI, Basel, Switzerland. This article is an open access article distributed under the terms and conditions of the Creative Commons Attribution (CC BY) license (http:/ / creativecommons.org/licenses/by/4.0/). 